\title{
Kada publika postane sekuritizujući akter: Promena bezbednosne paradigme u vreme pandemije COVID-19
}

\author{
Vladimir Ajzenhamer \\ Univerzitet u Beogradu, Fakultet bezbednosti, Republika Srbija \\ e-mail: ajzenhamer@fb.bg.ac.rs
}

\author{
Vanja Rokvić \\ Univerzitet u Beogradu, Fakultet bezbednosti, Republika Srbija \\ e-mail:vanjarokvic@fb.bg.ac.rs
}

SAŽETAK Rad konstatuje promenu postojeće bezbednosne paradigme i nudi predlog revizije teorije sekuritizacije u skladu sa aktuelnim bezbednosnim trendovima proizašlim iz novih praksi političkog i bezbednosnog komuniciranja, dominantno oslonjenim na internet i digitalno umrežavanje. Autori polaze od teze da je ekspanzija interneta, online medija i društvenih mreža, dovela do pojave nove vrste sekuritizacije, čiji stožer više ne čine država i njoj bliske elite, već su njeni nosioci digitalno umreženi građani. Takvu sekuritizaciju, koja se odvija horizontalno u svetu digitalnih društvenih mreža, a koja je u mnogome uslovljena fenomenom online viralnosti, autori određuju kao sekuritizaciju koja kreće „odozdo“ i daju joj naziv BTL (below the line) sekuritizacija. BTL sekuritizacija podrazumeva proces u kome građani, kojima je u izvornom teorijskom konceptu namenjena uloga (relativno pasivne) publike, za sebe prisvajaju atribute nosioca sekuritizujućeg diskursa, delaju kao sekuritizujući akteri i razvijaju sopstvene potencijale za implementaciju sekuritizujuće mere.

Opisana promena trenutno je najuočljivija na polju zdravstvene bezbednosti gde je delovanje tzv. antivakserskog pokreta dalo prve opipljive argumente u korist polazne tvrdnje ovog rada - hipoteze o viralnoj „detronizaciji” političkih elita sa pozicije ekskluzivnog sekuritizujućeg aktera. Na primeru antivakserskog pokreta uočljiva je još jedna bitna odlika novog sekuritizujućeg „trenda” - diskurzivno poistovećivanje države (kao legitimnog sekuritizatora) sa pretnjom koju je neophodno sekuritizovati. Naime, usled uvođenja nepopularnih mera za suzbijanje zdravstvenih pretnji (npr. vakcinacija, karantin i drugi vidovi socijalnih restrikcija) vlast, od strane građana, i sama biva percipirana kao egzistencijalna pretnja, čemu svedoči i viralni „sekuritizujući” narativ koji se, posredstvom društvenih mreža, širi među građanima Srbije nakon izbijanja globalne pandemije COVID-19.

Ključne reči: sekuritizacija, BTL, antivakseri, društvene mreže, viralnost, akter, publika, COVID-19, Republika Srbija.

Copyright (C) 2021 Institut za društvena istraživanja u Zagrebu - Institute for Social Research in Zagreb Sva prava pridržana - All rights reserved 


\section{Uvod}

Posmatrana u svom izvornom obliku teorija sekuritizacije predstavlja disciplinarnu parafrazu filozofije govornog čina Austina i Searlea (Austin, 1962.; Searle, 1969.) i njenu implementaciju u studijama bezbednosti. Pod sekuritizacijom podrazumevamo postupak „socijalne konstrukcije bezbednosnih pitanja“(Williams, 2003.:513), odnosno proces diskurzivnog prevođenja određenog pitanja u sferu bezbednosti i njegovo stavljanje u kontekst egzistencijalne pretnje čije otklanjanje zahteva hitnu primenu specijalne mere. Pored stožerne ideje o performativnoj snazi ilokucije (illocutionary act), na osnovu koje je Ole Waever izveo poistovećivanje bezbednosti i govornog čina (speach act), teorija sekuritizacije važno uporište ima i u ideji da legitimitet nosioca bezbednosnog narativa ne može uživati svako. Kako je uspešnost sekuritizacije uslovljena društvenim položajem i socijalnim kapitalom kojim govorni akter raspolaže (Buzan, Waever i de Wilde 1998.:33), a implementacija prihvaćene specijalne mere najčešće zavisi od mogućnosti pristupa monopolu sile, uloga sekuritizatora predstavlja prevashodno prerogativ države tj. političke vlasti i njoj bliskih elita (Waever, 1995.:57; Buzan i sur., 1998.:35, 40).

Međutim, kako tvrde autori ovog rada, uspon digitalnih društvenih medija i mreža tokom druge decenije XXI veka doveo je do tektonskih promena u praksi društvenog, političkog i bezbednosnog komuniciranja (Kastels, 2018.; Rosenau, 2008.; Sampson, 2012.; Petrović, 2016.; Hendricks i Hansen, 2016.; Vaidhyanathan, 2018.), čime se postepeno menjaju i ustaljena pravila sekuritizujuće igre, prvenstveno "tradicionalna” uloga običnih građana u procesu sekuritizacije. Naša osnovna pretpostavka je da su, zahvaljujući virtuelnom svetu društvenih medija i mreža, kao i fenomenu „viralnosti” (sadržaj koji se velikom brzinom širi internetom), građani širom sveta danas u poziciji da za sebe prisvajaju određene atribute nosioca sekuritizujućeg diskursa i da razvijaju sopstvene potencijale za implementaciju sekuritizujuće mere. Naznačena transformacija trenutno je najuočljivija na polju zdravstvene bezbednosti, gde je delovanje tzv. antivakserskog pokreta tj. pokreta za borbu protiv vakcinacije, dalo prve opipljive argumente u korist polazne tvrdnje ovog rada - hipoteze o viralnoj „detronizaciji” državnih elita sa pozicije ekskluzivnog sekuritizujućeg aktera.

Samo u nekoliko poslednjih godina online aktivnost antivakserskog pokreta, koju ćemo u nastavku rada analizirati kao primer novog oblika sekuritizacije, dovele su do povećanog otpora prema MMR vakcini širom sveta, što je posledično izazvalo porast broja zaraženih malim boginjama na tlu Evrope, SAD i država Jugoistočne Azije (Tobin, 2019.). Rastuća asertivnost ovih pokreta dovela je 2018. godine i do crnog bilansa sezone gripa u SAD, kada je zabeleženo čak 80.000 smrtnih slučajeva. Među umrlima se nalazio i veliki broj mladih koji, uprkos preporukama zdravstvenih organizacija, nisu bili vakcinisani protiv gripa (Hotez, 2019.:912). Takođe, u 53 države Evropskog Regiona Svetske zdravstvene organizacije (WHO) došlo je do porasta broja zaraženih 
morbilama, i to sa 5273 slučajeva registrovanih u 2016, na cifru od 83.540 u 2018. godini, dok je 2019. epidemija malih boginja u SAD dostigla vanredno velike razmere (Benecke i DeYong, 2019). Zbog svega navedenog WHO je 2019. godine otpor vakcinisanju uvrstila u top 10 pretnji javnom zdravlju (World Health Organization [WHO], 2019.).

Delovanje antivakserskog pokreta predstavlja pretnju koja nadilazi sektor javnog zdravlja i koja, zbog specifičnosti svojih posledica (moguće vaskrsnuće i brzo širenje gotovo išcezlih zaraza i umanjenje rezistentnosti na trenutno aktuelne zarazne bolesti), poseduje sposobnost da ugrozi sve nivoe i sektore bezbednosti. Stoga ovaj fenomen zaslužuje podrobnije naučno istraživanje, koje pored prikupljanja empirijske građe o organizovanom otporu vakcinaciji, podrazumeva i razvijanje adekvatnog teorijskog okvira koji bi doprineo boljem razumevanju delatnih principa koji stoje iza naglog uzleta antivakserske ideolgije. Autori ovog rada smatraju da je upravo teorija sekuritizacije podesan okvir za izučavanje antivakserskog online aktivizma, ali da na pomenuti fenomen ista može biti primenjena tek nakon ozbiljne revizije njenih centralnih pretpostavki.

U nastavku rada sugerisaćemo neophodnost promene postojeće bezbednosne paradigme i predložiti upravu jednu takvu reviziju. Naša polazna tvrdnja je da je ekspanzija interneta, online medija i društvenih mreža, dovela do pojave nove vrste sekuritizacije, čiji stožer više nije državocentričan tj. vezan isključivo za donosioce političkih odluka i njima bliske elite. Takvu sekuritizaciju, koja se odvija horizontalno u virtuelnom svetu društvenih mreža, i koja je u mnogome uslovljena fenomenom online viralnosti, mi ćemo odrediti kao sekuritizaciju koja kreće „odozdo“ i nazvati je BTL (below the line) sekuritizacija. Dok mainstream teorija sekuritizacije, na koju ćemo u nastavku rada referisati kao na ATL (abow the line) sekuritizaciju, počiva na konceptualnoj distinkciji između sekuritizujućeg aktera i publike, kao i na razdvajanju sekuritizujućeg aktera od referentnog objekta čiji je opstanak ugrožen, u osnovi BTL koncepta koji mi predlažemo leži ideja o brisanju jasne granice između sekuritizujućeg aktera, publike i referentnog objekta, koja je posledica sve većeg društvenog značaja virtuelnih društvenih mreža i platformi. Drugim rečima, u nastavku rada, na primeru online aktivnosti antivakserskog pokreta, ilustrovaćemo tvrdnju da je virtuelno umreženo društvo (Kastels, 2018.:21-34; Rosenau, 2008.:104-106, Petrović, 2016.:398-407) proizvelo novi vid sekuritizacije, BTL sekuritizaciju, koja omogućava običnim građanima tj. virtuelno umreženim pojedincima, da iz uloge publike pređu u ulogu sekuritizujućeg aktera, koji ne samo da ima moć da kreira sopstveni sekuritizujući diskurs, već poseduje i moć da, u određenom obimu, implementira samu specijalnu meru.

Rad je organizovan u četiri celine. U prvom poglavlju izložićemo centralne pretpostavke izvorne teorije sekuritizacije, kao i neke od najznačajnih kritika koji su na njen 
račun pristigle u protekle dve decenije. Drugo poglavlje je posvećeno kratkom istorijatu antivakserskog pokreta i opisu najvǎnijih ideja za koje se borci protiv vakcina zalažu. U trećem poglavlju predložićemo BTL sekuritizaciju kao teorijski okvir podesan za razumevanje ne samo online delovanja antivakserskog pokreta, već i ukupnog fenomena sekuritizujućeg diskursa koji se javlja na društvenim mrežama. Četvrto poglavlje, skoncentrisano na antivaksersko iskustvo Republike Srbije u doba pandemije COVID-19, predstavlja kratku studiju slučaja kojom ćemo argumentovati prethodno iznete tvrdnje o BTL sekuritizaciji.

\section{Osnovne postavke teorije sekuritizacije}

Teorija sekuritizacije razvijena je pod okriljem tzv. Kopenhaške škole koja pristup fenomenu bezbednosti temelji na filozofiji govornog čina. Sledeći Austinov koncept performativne izjave (performative utterence), Kopenhaška škola polazi od pretpostavke da je „artikulacija bezbednosti krucijalna forma bezbednosne akcije“ (Stritzel, 2007.:360). Uzevši proces sekuritizacije za stožerni koncept studija bezbednosti, autori Kopenhaške škole načinili su radikalni raskid sa tradicionalnim shvatanjem bezbednosti, u kome je centralnu ulogu igrala realistička paradigma. Usmereni na izučavanje međunarodne bezbednosti, svesni neophodnosti proširenja istraživačke agende koja je već početkom 80-ih godina prošlog veka počela da prevazilazi striktni okvir nacionalne bezbednosti, Barry Buzan i Ole Waever, dva najistaknutija imena Kopenhaške škole, započeće svoj rad na rekonceptualizaciji pojma bezbednosti kako bi stvorili analitički okvir podesan da obuhvati pretnje i referentne objekte koji izlaze iz vidokruga tradicionalnog i tradicionalno progresivnog shvatanja bezbednosti (Waever, 1995.:46-47). Usvojivši Waltzov analitički pristup, koji podrazumeva tri nivoa analize - čoveka, državu i međunarodni sistem (Buzan, 1983.), Buzan je započeo rekonceptualizaciju istraživanja u oblasti bezbednosti, koja će ubrzo rezultirati tzv. sektorskim pristupom. Uz koncept sekuritizacije, upravo će sektorska analiza, zasnovana na raščlanjivanju bezbednosti na više „sektora“1 određenih kriterijumom srodnosti odnosa i interakcija njenih konstituišućih jedinica, postati jedno od najprepoznatljivijih obeležja Kopenhaške škole (Buzan i sur., 1998.). $S$ druge strane, vodeći se idejom o performativnosti govornog čina, crpeći inspiraciju iz radova Austina, Searla, Derride i Butlerove, Waever će svoje istraživanje usmeriti u pravcu redefinisanja samog pojma bezbednosti, te će isti propitivati sa poststrukturalnog stanovišta. Za Waevera bezbednost nije tek puka datost, refleksija realnih spoljnih pretnji, već je reč o samoreferišućoj praksi uslovljenoj percepcijom i intencijom onoga

${ }^{1}$ Analitička svrha sektora je da omogući identifikovanje i diferencijaciju različitih vrsta interakcije između konstituišućih jedinica međunarodnog sistema. Kopenhaška škola razlikuje vojni, ekonomski, socijetalni, politički i sektor životne sredine. 
ko govori o bezbednosti. On bezbednost svodi na čin ilokucione ${ }^{2}$ transformacije određenog problema u bezbednosno pitanje, čime odbacuje tradicionalno vojno-političko shvatanje prema kome se suština bezbednosti ogleda u realnosti koja prethodi jeziku. Jednostavno rečeno, prevođenje određenog pitanja u bezbednosno pitanje nije nužno uslovljeno postojanjem prave egzistencijalne pretnje, već činom predstavljanja tj. „izgovaranja" datog pitanja kao pretnje (Buzan i sur., 1998.:24).

Autori Kopenhaške škole zauzimaju stanovište prema kome jezik ne samo da prethodi bezbednosti, već je i kreira. Stoga oni bezbednost definišu kao govorni čin per se putem koga se određeno javno pitanje prevodi u bezbednosnu sferu. Waewer konstatuje kako se, uz pomoć teorije jezika, prema bezbednosti možemo odnositi kao prema govornom činu i da je ,izgovaranje samo po sebi čin. Reći nešto znači učiniti nešto (kao u klađenju, davanju obećanja, imenovanju broda). Izgovarajući „bezbednost“, predstavnik države premešta određeni događaj u određenu oblast, i tamo zahteva specijalno pravo na upotrebu sredstava potrebnih za njegovo zaustavljanje“ (Waever, 1995.:55).

U skladu sa uverenjem da „više bezbednosti“ nije nužno dobra stvar (Waever, 1995.:46; Buzan i sur., 1998.:29), autori Kopenhaške škole ističu kako svako javno pitanje može biti predstavljeno (a u skladu sa time i rešavano) na nepolitizovan, politizovan i sekuritizovan način (Buzan i sur., 1998.:27). U prvom slučaju, država se neće baviti datim problemom i on ni na koji način neće biti pretvoren u predmet javne debate. U slučaju politizacije, pitanje postaje deo javne politike, što sa sobom povlači angažman državne uprave i alokaciju državnih resursa. Sekuritizacija, kao krajnja tačka spektra (suprotna nepolitizaciji), podrazumeva predstavljanje datog pitanja kao egzistencijalne pretnje, čime se zahteva primena specijalnih mera i opravdava akcija koja izlazi iz okvira standardnih političkih procedura. Svako javno pitanje može biti tretirano primenom jednog od pomenutih modus operandi-ja. Koje će rešenje biti primenjeno zavisiće od intencije države i njenih elita, kao i okolnosti u kojima se dato pitanje javlja/postavlja. Imajući u vidu da je sekuritizacija tek jedan od mogućih načina rešavanja pitanja, ona je od strane Kopenhaške škole okarakterisana kao potez kojim se politika izmešta izvan ustaljenih pravila demokratske političke igre i okvira „normalne“ političke prakse (Buzan i sur., 1998.:23, Balzacq, 2005.:171, Vuori, 2008.:66). ${ }^{3}$

2 Prema Austinovoj filozofiji jezika, rečenica može biti nosilac tri vrste postupka tj. „ऍ̌ina“ - lokucije, ilokucije i perlokucije, čije međusobne kombinacije određuju prirodu situacije izazvane govornim činom. Lokucija je čin jednostavnog kazivanja tj. izgovaranja rečenice. On podrazumeva upotrebu govora, odnosno iskaz koji sadrži određeni smisao i referencu. S druge strane, ilokucija se sastoji od artikulisanja lokucije i sam koncept govornog čina se u velikoj meri može poistovetiti sa njom. Nju možemo opisati kao čin izgovaranja namere ili zahteva da se uradi određena radnja. Perlokucija predstavlja čin uspešnog izvršenja određene namere i podrazumeva efekte na osećanja, uverenja, misli, namere ili aktivnosti ciljane publike (Austin, 1962; Thierry Balzacq, 2005: 175; Stojanović Prelević, 2013:20-21).

3 Važno je napomenuti da je Waever sekuritizaciju koncipirao kao primarni segment binarne opozicije sekuritizacija-desekuritizacija. Potonji koncept pretpostavlja potez suprotnog dejstva, koji Lene Hansen opisuje kao „izlazak iz bezbednosti“ (Hansen, 2012.:526). Reč je o „raskidu“ sa politikom specijalnih mera i povratku „problematičnog“ pitanja u okvir regularnog političkog debatovanja i pregovaranja (Buzan i sur., 1998.:4, 29). 
Posmatran u svom izvornom obliku, koncept sekuritizacije može biti raščlanjen na dve bazične tj. konstituišuće ideje (Stritzel, 2007.:358). Prva noseća ideja ogleda se u određenju sekuritizacije kao interakcije između sekuritizujućeg aktera i publike, koja se realizuje posredstvom performativnog govornog čina koji, u procesu kreiranja bezbednosnog pitanja, poprima formu sekuritizujućeg poteza. Interakcija, a samim time i proces sekuritizacije, kompletira se onda kada publika prihvati opravdanost prevođenja pitanja u sferu bezbednosti i da saglasnost za primenu specijalne mere. Druga ideja naglašava važnost seta ilokuciono-kontekstualnih uslova tzv. facilitating conditions-a, koji utiču na uspeh govornog čina, a samim time i na uspešnost sekuritizacije.

Kada je u pitanju sekuritizujući akter, on predstavlja kreatorsku instancu zaduženu za prevođenje (ne)politizovanog pitanja u domen bezbednosti. U pitanju je pojedinac ili grupa koja odlučuje da li nešto treba tretirati kao egzistencijalnu pretnju, i koja u skladu sa time preduzima sekuritizujući potez, odnosno izvodi/izgovara bezbednosni govorni čin (Buzan i sur., 1998.:34, 40). No, važno je istaći da ulogu sekuritizujućeg aktera ne može igrati bilo ko. Ona je u Waeverovoj i Buzanovoj teoriji rezervisana prevashodno za predstavnike države i elite koje orbitiraju oko državocentričnih centara moći (Waever, 1995.:57; Buzan i sur., 1998.:35, 40). Kao najčešće nosioce ove uloge oni navode političke lidere, birokratije, vlade, lobiste i grupe za pritisak. Juha Vuori, koji smatra da uvođenje specijalnih mera ne mora biti jedini cilj sekuritizacije (Vuori, 2008.; Ejdus, 2012.:112) već da ona može biti i u službi šireg varijeteta političkih ciljeva, donekle proširuje listu aktera, te među njih ubraja npr. naučnike i novinare, ali i sam priznaje da oni moraju raspolagati socijalnim kapitalom koji bi im omogućio pristup donosiocima odluka (Vuori, 2008.:77), čime dodatno potvrđuje tezu o državocentričnosti i ekskluzivnosti ovog procesa. Drugim rečima, jasno je da nije svako pozvan da govori "jezikom bezbednosti“, već da su država i njene elite te koje polažu specijalno pravo na preimenovanje određenog problema u bezbednosno pitanje. Upravo ovaj segment teorije sekuritizacije mi ćemo propitivati u nastavku rada, iznoseći predlog za njegovu reviziju u skladu sa novim bezbednosnim pretnjama vezanim za delovanje antivakserskog pokreta na društvenim mrežama.

Treba imati na umu da Kopenhaška škola kao najznačajniji segment procesa sekuritizacije vidi upravo govorni čin. ${ }^{4}$ On nije isto što i percepcija pretnje. Kako Huysmans primećuje, percepcija pretnje se odnosi na nešto što dolazi „spolja“, dok je govorni čin samoreferišući. U slučaju potonjeg, pretnja nastaje isključivo kao posledica „izgovaranja bezbednosti“ tj. sam iskaz o pretnji konstituiše pretnju (Huysmans, 1998.a:492). Međutim, sekuritizujući potez podrazumeva više od pukog lokucionog konstatovanje pretnje. Govorni čin mora biti ilokucioni iskaz, koji istovremeno poseduje i svojstva

${ }^{4} \mathrm{U}$ potonjim interpretacijama autori izvan Kopenhaškog kruga su težište sekuritizacije videli bitno drugačije. Tako je Balazcq konceptualizuje kao dominantno perlokucionu, Hansen je tumači kao „ućutkujuću“ i telesno potčinjavajuću, dok Bigo u njoj vidi tehnokratsku praksu (Strizel, 2007.:376). 
„performativa“. Tek kao takav on može igrati ključnu ulogu u procesu prevođenja određenog pitanja u sferu bezbednosti. Naime, ilokucioni čin poseduje moć da kod publike izazove željeni perlokucijski efekat koji se sastoji u prihvatanju pomenute transformacije i davanju saglasnosti za sprovođenje specijalne mere. Otuda, da bi sekuritizujući akter ostvario svoj naum, on mora učiniti znatno više od lokucijskog obznanjivanja bezbednosne pretnje. On „arhitekturu“ bezbednosnog iskaza mora utemeljiti na ilokucionom proklamovanju „egzistencijalne“ pretnje čije otklanjanje zahteva hitnu primenu specijalne mere, koja ne može biti realizovana bez podrške publike (Buzan i sur., 1998.:24, 27). Pritom, on mora voditi računa o tome da njegov iskaz sadrži takav bezbednosni argument koji će „uvek uključiti dva predviđanja: Šta će se dogoditi ukoliko ne preduzmemo 'bezbednosnu akciju' (pretnja) i šta će se desiti ukoliko je preduzmemo (kako prihvaćena bezbednosna politika treba da deluje?) “ (Buzan i sur., 1998.:32). Ipak, bez obzira na centralnu ulogu koja mu je dodeljena u procesu sekuritizacije, govorni čin tj. sekuritizujući potez per se nije dovoljan za uspeh sekuritizacije. Za njen uspeh neophodan je i pristanak publike.

Iako se na prvi pogled može steći utisak da je u lancu sekuritizacije akter važniji od publike, uspešnost procesa zavisi prvenstveno od potonje. Kako to primećuju Buzan, Waever i De Wilde „o sekuritizaciji ne odlučuje sekuritizator, već publika govornog čina" (Buzan i sur, 1998.:31). Uloga publike namenjena je zaintresovanoj javnosti, najčešće građanima, odnosno narodu, koji u najvećem broju slučajeva istovremeno igra i ulogu referentnog objekta sekuritizujućeg diskursa tj. objekta za čiju egzistenciju sekuritizujući akter tvrdi da je ugrožena predočenom pretnjom. Diskurs koji pretenduje da određeno pitanje predstavi kao egzistencijalnu pretnju po referentni objekat, sam po sebi, ne čini sekuritizaciju, on je tek ,sekuritizujući potez, ali pitanje je sekuritizovano samo kada ga publika prihvati kao takvo" (Buzan i sur., 1998:25, 34). Ukoliko podrška publike izostane, sekuritizujući potez nije urodio plodom, te se ne može govoriti o sprovedenoj sekuritizaciji. Pri čemu Kopenhaška škola ne smatra da uspešnost sekuritizacije treba premeravati isključivo kriterijumom prihvatanja specijalne mere, već da je za njenu realizaciju dovoljno da proizvede raspravu o egzistencijalnoj pretnji i da debata povodom nje dobije na zvučnosti taman onoliko koliko je neophodno za „stvaranje platforme sa koje je moguće legitimisati hitne mere ili druge korake koji ne bi bili mogući bez formiranja diskursa o egzistencijalnim pretnjama, tački bez povratka i neophodnosti“" (Buzan i sur., 1998.:25).

Kada su u pitanju facilitating conditions tj. preduslovi za uspešno sprovođenje sekuritizacije, sledeći Austinova pravila "glatkog ili 'srećnog' funkcionisanja performativa" (Austin, 1962.:14-15), Buzan, Waever i De Wilde njih vide kao sinergiju internih i eksternih aspekata govornog čina. Pre svega, govorni čin mora slediti provereni šablon gramatike bezbednosti koji podrazumeva „konstruisanje zapleta koji uključuje egzistencijalnu pretnju, tačku bez povratka i mogući izlaz" (Buzan i sur, 1998.:32-33). Takođe, on mora uzeti u obzir i „dijalekte" određenih sektora, odnosno voditi raču- 
na o razlikama između ključnih pojmova karakterističnih za svaki sektor ponaosob. Tako npr. u socijetalnom sektoru treba govoriti o identitetu, u političkom sektoru o suverenosti i priznanju, dok u sektoru zaštite životne sredine akcenat treba staviti na održivost (Buzan i sur., 1998.:33). Kada su u pitanju spoljni aspekti govornog čina, neophodno je da sekuritizujući akter poseduje određeni socijalni kapital i autoritet (ne nužno zvanični) koji mu daju legitimitet nosioca bezbednosnog diskursa. Uz to, govorni čin ima veće šanse za uspeh ukoliko njegov sadržaj referiše na objekte koje publika i inače doživljava kao preteće (Buzan i sur, 1998.:33). U nastavku rada vratićemo se na ove preduslove kako bi smo pokazali kako u slučaju onoga što mi nazivamo BTL sekuritizacijom facilitating conditions podrazumevaju drugačiji set ilokucino-kontekstualnih pravila.

Na kraju ovog poglavlja potrebno je pomenuti i kritike upućene na račun teorije sekuritizacije. One obuhvataju širok dijapazon i kreću se u rasponu od interpretiranja sekuritizacije u ključu političke teorije Karlla Schmitta (Huysmans, 1998.b; Williams, 2003.:512, 515-521; za širu raspravu videti i Ejdus, 2009:9-16), preko insistiranja na njenoj temeljnoj reviziji jačanjem socijalkonstruktivističkog okvira i odricanjem od postsrukturalističkog težišta (Stritzel, 2007.), pa sve do angažovanije, društvene kritike, koja teoriju sekuritizaciju vidi kao akademski instrument prolongiranja prakse marginalizacije žena (Hansen, 2000.) pa čak i rasizma (Howell i Richter- Montpetit, 2020.). Ipak, mi ćemo se ovde osvrnuti isključivo na one kritike za koje smatramo da su od neposredne koristi za nadogradnju koncepta koju ćemo ponuditi u nastavku rada. Tako je za nas od velike važnosti Williamsova primedba da je Kopenhaška škola svela komunikativnu akciju prevashodno na govorni čin, ignorišući činjenicu rastućeg značaja televizuelnih slika po savremenu političku komunikaciju. Mi ćemo slediti ovu ideju i proširiti Williamsovo insistiranje na širem razumevanju medijuma, struktura i institucija savremene političke komunikacije (Williams, 2003.:512, 524-528), uključivanjem viralnog vizuelnog sadržaja kao sastavnog dela virtuelnog sekuritizujući diskursa, odnosno onoga što mi nazivamo BTL sekuritizacijom.

U obzir ćemo uzeti i McDonaldovu zamerku da autori Kopenhaške škole, pored toga što iz svoje teorije isključuju druge komunikacijske forme, poput slika ili praksi (o čemu govori i Williams), takođe imaju i skučen pogled na ulogu sekuritizujućeg aktera, koju svode isključivo na „one glasove koji se smatraju institucionalno legitimnim da govore u ime određenog kolektiva, uglavnom države“ (McDonald, 2008.:564). McDonald upozorava da je Kopenhaška škola, zaključkom o bezbednosti kao fenomenu čija artikulacija ostaje prevashodno u okviru države (Waever, 1995.:47-49; Buzan, 1998.:32-33), od govornog čina načinila prerogativ moćnih. Prema njegovom mišljenju teorija sekuritizacije bi trebalo da obrati više pažnje na marginalizovane aktere koji se ne nalaze na pozicijama moći, i koji su do sada „u najbolju ruku predstavljani kao publika koja kolektivno može dati pristanak ili osporiti sekuritizujuće poteze, ili u najgorem slučaju kao pasivni recipijenti diskursa koje serviraju elite" (McDonald, 
2008.:574). Upravo na tragu ove primedbe, mi ćemo predložiti prošireno razumevanje uloge govornog aktera njenom ekstenzijom na virtuelni sekuritizujući diskurs i učesnike društvenih mreža kao njegove emitere.

Poslednja važna kritika koju ćemo uključiti u ovaj rad je ona koju je na račun izvornog koncepta teorije sekuritizacije uputio Thierry Balzacq (Balzacq, 2008.; Balzacq., 2011:31-55). Balzacq kritikuje praksu analitičke redukcije sekuritizujućeg diskursa na ilokucioni segment govornog čina, insistirajući na značaju konteksta i publike. On ukazuje na paradoks koji se krije u samom tkanju teorijske šeme Waevera, Buzana i njihovih saradnika. Naime, ukoliko je bezbednost samoreferišući čin (Buzan, 1998.:24) određen isključivo ilokucionom dimenzijom govornog čina i njenom performativnošću, otkuda onda instistiranje na presudnom značaju percepcije i prihvatanja sekuritizujućeg poteza od strane publike, iz čega proizilazi da je sekuritizacija intersubjektivan proces (Buzan, 1998.:19, 25, 29-31, 57, Huysmans, 1998.a: 493)? Stoga Balazacq i još nekolicina drugih autora (Strizel, 2007.:362-363; Leonard i Kaunert, 2011.) smatra da analitički fokus mora biti znatno usmereniji ka raspoloženju publike i eksternoj realnosti (okolnostima izvan govornog čina) kao preduslovu pridobijanja podrške za uvođenje specijalne mere. Drugim rečima, ključ razumevanja sekuritizacije ne krije se činu ilokucije već u perlokucijskom efektu koji se njome postiže. Kontekst i publika moraju biti na prvom mestu.

U narednom poglavlju naša pažnja biće usmerena upravo na ovaj segment sekuritizujućeg procesa. Pošavši od pomenutih kritika Williamsa, McDonalda i Balazacqa mi ćemo u nastavku rada ukazati na neophodnost prepoznavanja značajno asertivnije funkcije publike u vremenu dominacije virtuelne komunikacije i sve većeg uticaja tzv. viralnih sadržaja. Fokusiranjem na transformaciju publike iz uloge relativno pasivnog recipijenta ${ }^{5}$ sekuritizujuće poruke u ulogu kreatora virtuelnog sekuritizujućeg diskursa, autori rada predložiće novi model sekuritizacije podesan da uhvati korak sa promenama koje je sobom nosi virtuelno umreženo društvo.

\section{Kratka istorija antivakserskog pokreta}

Tragove borbe protiv vakcinacije možemo naći još u propovedi engleskog sveštenika Edmunda Masseya iz 1722. godine (Massey, 1722.), koja diže glas protiv opasne prakse inokulacije koju Massey naziva „vražjim poduhvatom“, odnosno pokušajem prkosa božijoj kazni namenjenoj čoveku zbog njegovih greha (Husein i sur., 2018:2). Istraživanje doktora Edwarda Jennera (Riedel, 2005.) i prvo vakcinisanje 1796. godine, a potom i uvođenje zakonske obaveze vakcinacije u Velikoj Britaniji 1853. godine,

${ }^{5}$ Reč je o još jednom paradoksu teorije sekuritizacije. Iako Waever eksplicitno navodi kako sekuritizacija ne počiva na tradicionalnom „pošiljalac-primatelj“ modelu komunikacije, on istovremeno usvaja (gotovo istovetan) model razmene poruka po principu „govornik-publika“ (Strizel, 2007.:363). 
dovelo je do formiranja prvih antivakserskih pokreta u ovoj državi. Anti-vakciona liga (Anti-Vaccination League) osnovana je 1853, dok je 1867. godine formirana Liga protiv obaveznog vakcinisanja (Anti-Compulsory Vaccination League), čija je misija bila „zaštita individualnih sloboda 'napadnutih' od strane Parlamenta“ (Husein i sur., 2018:2). U biltenu ovog pokreta može se pročitati sledeće: „kako je parlament, umesto da čuva slobodu svojih podanika, uzurpirao ovu slobodu proglašavajući dobro zdravlje krivičnim delom, kažnjivo novčanom kaznom ili zatvorom, nametnuto savesnim roditeljima, parlament zaslužuje javnu osudu" (Wolfe i Sharp, 2002.:431). Wolfe and Sharp navode da se u periodu između 1870. i 1880. godine pojavio veliki broj časopisa i knjiga u kojima se zagovara borba protiv vakcinacije, što je, između ostalog, uticalo na osnivanje antivakserskih pokreta širom Evrope. Ovi autori navode, da je u Stokholmu 1872, kao posledica delovanja pomenutih pokreta, procenat vakcinacija opao za oko 40\%. Tokom 1885. godine u Lesteru su održane masovne demonstracije na kojima su ljudi nosili dečije mrtvačke sanduke i lutku doktora Jennera. Ovakav vid pritiska na britanske vlasti rezultirao je 1898. godine odlukom parlamenta da ukine kaznu za roditelje koji ne žele da vakcinišu svoju decu. Pod uticajem ideja engleskog aktiviste Williama Tebba ${ }^{6}$ (Tebb, 1893.), antivakserske ideje prelaze okean i stiču svoje sledbenike u SAD. Aktivnosti udruženja poput Anti-vakcionog društva Amerike (Anti-Vaccination Society of America) osnovanog 1879. godine, Lige za borbu protiv obavezne vakcinacije Nove Engleske (New England Anticompulsory Vaccination League) osnovane 1882. godine ili Anti-vakcione lige grada Njujorka (Anti-Vaccination League New York City) osnovane 1885. godine, dovela su do suspenzije zakona o obaveznom vakcinisanju u nekoliko saveznih država.

Delovanje pokreta protiv obavezne vakcinacije nastavljeno je i tokom XX veka. Pojedini događaji poput tzv. Cutter incidenta dali su novi momentum ovim pokretima. Naime, 1955. godine u SAD, greška u primeni polio vakcine farmaceutske kompanije „Cutter Laboratories“, dovela je do 40.000 novih slučajeva zaraze, 200 slučajeva (različitih stupnjeva) paralize i 10 smrtnih ishoda (Fitzpatric, 2006.: 156). Nakon objavljivanja rada o neurološkim komplikacijama nakon vakcinacije protiv velikog kašlja (Kulenkampff, Schwartzman i Wilson, 1974.), u Velikoj Britaniji došlo je do rapidnog smanjenja broja preduzetih vakcinacija, i to sa $81 \% 1974$. godine na $31 \% \mathrm{u}$ 1980. godini, što je za posledicu imalo izbijanje epidemije velikog kašlja. Potom je u SAD, 1976. godine, nakon primene vakcine protiv svinjskog gripa uočen blagi porast Guillain-Barré sindroma, što je dovelo do obustavljanja imunizacija. ${ }^{7}$ Ovi incidenti doprineli su daljem rastu nepoverenja prema vakcinama i vakcinaciji. Ipak, najzna-

\footnotetext{
${ }^{6}$ Iako nije imao medicinsko znanje Tebb je 1893. objavio knjigu o tome kako vakcine doprinose širenju lepre.

7 Opravdanost ove mere delimično je potvrđena istraživanjem iz 2003. godine, koje je pokazalo da su pojedinci vakcinisani 1976. godine zaista podložniji razvijanju Guillain-Barré sindroma (Centers for Disease Control and Prevention [CDC], 2020.)
} 
čajniji uticaj na antivakserske pokrete izvršio je rad Andrewa Wakefielda, objavljen 1998. godine u prestižnom naučnom časopisu „Lancet“. Wakefield je izneo tvrdnju da MMR vakcina dovodi do autizma, čime je uticao na odluku velikog broja roditelja u zapadnim zemljama da ne vakcinišu svoju decu, što je za posledicu imalo epidemiju malih boginja.

Iako je Wakefieldovo istraživanje osporeno, uklonjeno iz časopisa, a njegovo ime je izbrisano iz medicinskog registra Ujedinjenog Kraljevstva, pobornici antivakcinacije stali su u njegovu odbranu. U intervjuu za New York Times, J.B. Handley, jedan od osnivača organizacije Generation Rescue, izjavio je kako je za njihovu zajednicu Andrew Wakefield „Nelson Mandela i Isus Hrist u jednom čoveku“ (Dominus, 2011.:36). U kojoj meri je nakon objavljivanja Wakefieldovog rada kampanja protiv MMR uzela maha, govori i činjenica da pojedini autori svoja istraživanja dele na pre-Wakefield i post-Wakefield eru (Calvet, Asthon i Garnett, 2013.). Calvet i njegovi saradnici navode da je nakon Wakefield-ovog rada u Velikoj Britaniji procenat MMR vakcinacija pao sa $92 \%$ u 1995. godini na $84 \%$ u 2002. godini (Calvet i sur, 2013.:1625), da bi 2008. godine u ovoj državi bila proglašena epidemija malih boginja (Hussain i sur., 2018:3).

Početkom XXI veka, modus operandi antivakserskog pokreta prošao je kroz ubrzanu transformaciju iniciranu novomilenijumskom tehnološko-informacionom revolucijom. Bezobalnost virtuelnog prostora, kreiranog zahvaljujući internetu i društvenim mrežama, omogućila je brže širenje i znatno veći domet antivakserskih ideja. Ukoliko uzmemo u obzir podatak koji je, u januaru 2015. godine, objavio „Huffington Post“, da je po broju korisnika Facebook premašio broj stanovnika najveće države sveta, te da je sa cifrom od 1.39 milijardi ljudi ova društvena mreža postala „veća“ od Kine (Hendricks i Hansen, 2016.:36), onda je jasno da su savremeni antivakserski pokreti dobili mogućnost da svoju poruku prezentuju znatno široj publici nego što je to bio slučaj samo nekoliko decenija ranije. Asertivnost njihovog delovanja ojačana je činjenicom da je internet olakšao pristup fondu stručnog ili naučnog znanja, te da je i „medicinsko znanje koje je nekada bilo na raspolaganju ekskluzivno medicinskim stručnjacima sada postalo dostupno svima i može biti deljeno u postovima koji postaju 'viralni'“" (Benecke i DeYong, 2019:2), što omogućava antivakserima da svoju argumentaciju grade na daljim interpretacijama zvaničnih podataka globalne zdravstvene zajednice. Ipak, od presudnog značaja za njihov novomilenijumski uzlet imalo je virtuelno umrežavanje, koje je antivakserskim pokretima omogućilo lakše emitovanje i bržu recepciju poruke, i to ne samo zahvaljujući fenomenu društvenih mreža, već i uz pomoć brojnih formi i tehnika virtuelne komunikacije koje obezbeđuju veću viralnost plasiranog sadržaja npr. audio-vizuelni klipovi, objave/statusi, twitt-ovi, gif-ovi, meme-i i sl.

Pomenutu tvrdnju o značaju virtuelnog umrežavanja za širenje antivakserskih ideja možemo lako potkrepiti rezultatima brojnih istraživanja sprovedenih u poslednjih 
dve decenije. Tako npr. online pretraga, koju su 2001. godine, na osnovu ključnih reči „vakcinacija“ i „imunizacija“, sproveli Davies, Chapman i Lesak, koristeći sedam vodećih internet pretraživača, pokazala da $43 \%$ rezultata čine sajtovi sa antivakserskim sadržajem (Davies, Chapman i Lesak, 2001.:22). U istraživanju koje su 2004. godine sproveli Zimmerman i saradnici analiziran je sadržaj antivakserskih poruka na internetu. Njihov zaključak bio je da sajtovi koji propagiraju štetnost vakcina svoju argumentaciju grade oko sledećih tvrdnji - da vakcine uzrokuju bolest, da imaju samo privremen efekat, da su deo (globalne) zavere, da ugrožavaju građanske slobode, da predstavljaju uvertiru u totalitarni vid vladavine sl. Takođe, ovi autori primećuju kako antivakserske internet stranice često promovišu alternativne vidove lečenja i igraju na kartu emocija (Zimmerman i sur., 2005.). Sličnu obzervaciju iznose i Betsch i saradnici, koji ističu kako se na svakom drugom antivaks sajtu mogu naći sadržaji sa potresnim ličnim pričama i fotografijama dece koja su navodno bolesna usled vakcinisanja (Betsch i sur., 2010.).

Analiza video sadržaja koji imaju veze sa vakcinacijom na internet platformi YouTube, koju su 2007. godine sproveli Keelan, Pavri-Garcia, Tomlinson i Wilson pokazala je da čak $32 \%$ analiziranog materijala sadrži antivakserske poruke, kao i da je rejting ovih video klipova veći, i da oni poseduju veći broj pregleda od onih koji propagiraju benefite vakcinacije (Keelan i sur., 2007:2482). Istraživanje medicinske literature na engleskom jeziku koja se bavi temom vakcinacije, publikovane u periodu od 20092012, koje su sproveli Yaqub, Sevdalis, Chataway i Castle-Clark pokazuju da je internet čest izvor informacija o vakcinama, kao i to da na stavove bitno utiče nedostatak informacija, pogrešne (lažne) informacije i stepen poverenja u zvanične institucije (Yaqub i sur., 2014:7). Ujedno, ovo istraživanje pokazalo je da otpor vakcinisanju raste sa pojavom epidemija/pandemija, kao što je bio slučaj sa izbijanjem pandemije svinjskog gripa 2009. godine. Rezultati istraživanja sprovedenih u Francuskoj (Chanel i sur., 2011.:142) i Grčkoj (Sypsa i sur., 2009) pokazuju da je u ovim državama, tokom pandemijske 2009. godine, došlo do značajnog rasta opiranja vakcinaciji upravo protiv virusa gripa tipa $\mathrm{A}(\mathrm{H} 1 \mathrm{~N} 1)$.

Istraživanje Wellcome Global Monitor 2018, u segmentu posvećenom stavovima prema vakcinaciji, pokazalo je da 73\% populacije Severne Evrope veruje u bezbednost vakcina, dok je ovaj procenat u Zapadnoj Evropi znatno manji. Naime, u Zapadnoj Evropi samo $59 \%$ stanovništva veruje da vakcinacija sa sobom ne nosi nikakav rizik, ${ }^{8}$ dok ovaj procenat u Istočnoj Evropi pada na $40 \%$ gradana (Wellcome Trust [Wellcome], 2018.).

8 Interesantno je da je, posmatrano u nacionalnim okvirima, upravo jedna zapadnoevropska država prva u svetu po skepticizmu prema vakcinama. Naime ovo istraživanje pokazalo je da svaki treći Francuz ne veruje da je vakcinacija u potpunosti bezbedna. 
Nakon pojave malih boginja u SAD 2019. godine „The HKS Misinformation Review" sproveo je istraživanje u kojem je učestvovalo 2500 Amerikanaca. Istraživanje je pokazalo da su korisnici tradicionalnih medija bolje informisani o vakcinama od korisnika društvenih mreža. Prema ovom istraživanju $18 \%$ učesnika veruje da vakcina uzrokuje autizam, $15 \%$ se slaže sa tvrdnjom da su vakcine pune otrova, 19\% smatra da je bolje razviti imunitete tako što će se razboleti nego primiti vakcinu (Stecula, Kuru i Jamieson, 2020.). Najnovije istraživanje iz ove oblasti sprovedeno 2020. godine obuhvatilo je istraživanje facebook-ovog alata Ad Archive korišćenjem ključne reči "vakcina" (Jamison i sur, 2019.). Analizirano je 309 reklama od kojih je 163 (53\%) bilo za vakcinisanje i $145(47 \%)$ protiv vakcinisanja. Uočeno je i to da su reklame protiv vakcinisanje tematski uniforme i naglašavaju štetnost vakcina. Izveštaj Moving the Needle koji je 2018. godine pripremilo Kraljevsko udruženje za javno zdravlje (RSFPH) navodi podatak da je u Velikoj Britaniji 41\% roditelja dece uzrasta do 18 godina bilo izloženo negativnim porukama o vakcinaciji putem društvenih medija (Royal Society for Public Health [RSFPH], 2018.:29).

\section{BTL sekuritizacija: publika u ulozi sekuritizujućeg aktera}

Imajući u vidu rezultate pomenutih istraživanja nije teško izvući zaključak da na Zapadnoj hemisferi organizovani otpor vakcinaciji prerasta u ozbiljan izazov državi koja je, donedavno, zahvaljujući monopolu nad bezbednosnim diskursom, uživala eksluzivitet statusa legitimnog sekuritizujućeg aktera. Naša tvrdnja je da je sekuritizujući ekskluzivitet elita danas ugrožen i da je ekspanzija virtuelnih društvenih medija i mreža omogućila građanima da političkim vlastima osporavaju bezbednosni legitimitet. Zahvaljujući virtuelnoj društvenoj umreženosti tradicionalni sekuritizujući model, u kome je građanima namenjena uloga realtivno neaktivne publike, doveden je u pitanje. Građani posredstvom interneta postaju kreatori sopstvenog bezbednosnog diskursa, čime državnim elitama oduzimaju prerogative nosioca sekuritizacije i prisvajaju za sebe ulogu sekuritizatora. Ovaj proces odvija se dominantno u virtualnoj tj. online zajednici ali su, kako ćemo to u ovom poglavlju i pokazati, njegove implikacije po „realno" društvo itekako uočljive.

S obzirom na to da ovaj novi vid sekuritizacije ne dolazi od elite već iz redova „običnih" tj. u politiku neinvolviranih građana, nju ćemo označiti kao horizontalnu sekurtizaciju, koja nastaje „ispod linije“ politike i nadenućemo joj adekvatan naziv preuzet iz marketinškog vokabulara. Skraćenica BTL (below the line) u marketingu označava vođenje kampanje alternativnim sredstvima, koja se nalaze „ispod linije“ tehnika i sredstava kojima se koriste mainstream mediji, poput televizije ili radija. Mainstream marketinške kampanje etiketiraju se kao ATL (abow the line), te ćemo skladno tome ovu skraćenicu takođe iskoristiti kako bi smo njome označili tradicionalno shvatanje sekuritizacije. Kako tradicionalna sekuritizacija kreće „odozgo“ i podrazumeva proces u kome državne elite uživaju: a) poziciju legitimnog sekuritizujućeg aktera; b) otvoren 
pristup širokoj paleti medijskih resursa (televizija, radio i štampa), putem kojih sekuritizujuća poruka stiže do ciljane publike; c) raspoloživost monopola sile, kao garancije poštovanja specijalne mere; dodavanje prefiksa ATL čini nam se više nego opravdanim. Za dodavanje prefiksa BTL u slučaju sekuritizacije čiji su nosioci obični građani, takođe postoje čvrsti argumenti jer se radi o akterima kojima je, strukturom raspodele moći u društvu, status legitimnog sekuritizatora uskraćen, čime im je ujedno onemogućen pristup bezbednosnom diskursu, mainstream medijima i instrumentima sile. Stoga će nam skraćenica BTL pomoći da što jasnije podvučemo razliku između tradicionalne (ATL) sekuritizacije i one koja nastaje među nekadašnjom publikom koja se, zahvaljujući internetu i društvenim medijima i mrežama, sve više ponaša kao sekuritizujući akter.

Kada je izbor termina u pitanju potrebno je napomenuti i sledeće. Iako u prvi plan ističemo zavisnost BTL sekuritizacije od interneta, smatramo da naziv koji bi više upućivao na njen online karakter ne bi bio sasvim adekvatan. Ukoliko bi smo na nju referisali kao na „virtuelnu“ sekuritizaciju, to bi implicitno podrazumevalo i njenu odvojenost od materijalne realnosti, što, kada je u pitanju BTL sekuritizacija, svakako nije slučaj jer ona izaziva veoma „opipljive“ posledice. Označiti je kao „digitalnu“ ili online sekuritizaciju takođe bi moglo navesti na pogrešan zaključak da je reč o procesu isključivo vezanom za internet. S druge strane, „viralna sekuritizacija“ je pojam koji bi znatno više odgovarao procesu koji pokušavamo da opišemo, međutim, s obzirom na to da je reč o izvorno medicinskom terminu, kojim se ukazuje na zaraznost i veliku brzinu širenja virusa, ovom rešenju bi se opravdano moglo prigovoriti to da i ATL sekuritizaciju odlikuje svojstvo viralnosti - brzo širenje sekuritizujuće poruke uz pomoć mainstream medija. Otuda ćemo se, dosledno latinskom principu nomen est omen, opredeliti za termin BTL sekuritizacija, jer nam prefiks BTL omogućava da u njegovo značenje integrišemo sva prethodno pomenuta svojstva (online kontekst, virtuelni modus operandi i viralnost) a da pritom iz vida ne izgubimo poreklo (građani tj. publika) i realne implikacije (posledice primene specijalne mere) ovog oblika sekuritizacije.

Distinkcija između ATL i BTL sekuritizacije, prvi je preduslov izgradnje teorijskog aparatusa neophodnog za bolje razumevanje viralnog bezbednosnog diskursa koji kreiraju grupe i pokreti poput antivaksera. Sledeći preduslov jeste prihvatanje pretpostavke o brisanju jasne granice između sekuritizujućeg aktera, publike i referentnog objekta, kao i usvajanje teze da antivakcioni diskurs prisutan u društvenim medijima i na društvenim mrežama sledi pravila performativnog govora i logiku sekuritizujućeg diskursa, te da samim time on jeste sekuritizujući diskurs.

Kako smo već napomenuli, kopenhaški ATL koncept sekuritizacije podrazumeva državne elite u ulozi sekuritizujuće instance zadužene za prevođenje (ne)politizovanih pitanja u domen bezbednosti (Waever, 1995.:57; Buzan i sur., 1998.:35, 40). Država, odnosno njeni glasnogovornici, su ti koji odlučuju o tome šta treba imenovati 
i tretirati kao egzistencijalnu pretnju (Buzan i sur., 1998.:34, 40). Građanima je u procesu ATL sekuritizacije namenjena uloga relativno pasivne publike pred koju se iznosi ilokucioni argument o egzistencijalnoj pretnji i zahteva saglasnost sa primenom specijalne mere, kojom se postiže željeni perlokucijski efekat. Ipak, delovanje antivakserskog pokreta pokazalo je nosilac sekuritizacionog diskursa ne mora nužno biti vezan za državocentrične izvore moći i njene resurse, te da umreženi građani, služeći se prednostima horizontalne komunikacije putem interneta (Kastels 2018.:27; Rosenau, 2008.:104) - velikom brzinom razmene informacija, neposrednijim vidom komunikacije, delenjem i kreiranjem različitih audio-vizuelnih sadržaja i sl, mogu odaslati bezbednosnu poruku, koja u veoma kratkom roku može dopreti do veoma brojne publike i pridobiti njenu pažnju i saglasnost.

Jedno od najvažnijih pitanja na koje moramo odgovoriti kada analiziramo fenomen izmeštanja sekuritizujućeg stožera iz krugova elita u krug šireg građanstva jeste pitanje legitimiteta. Naime, zašto bi obični građani koji u ATL konceptu sekuritizacije nisu pozvani da javno govore o bezbednosti uopšte zavredeli pažnju, a kamoli poverenje ostatka umreženog građanstva? Drugim rečima, ukoliko u realnom svetu pristup bezbednosnom diskursu nije omogućen svakome, zašto bi onda drugačije bilo i u virtuelnom svetu društvenih medija i mreža? Potpuni odgovor na ovo pitanje zahtevao bi opsežnu elaboraciju na temu sudara fenomena tzv. postistine i koncepta ontološke bezbednosti, koja bi po svom obimu prevazišla ovaj rad. No, za nas će biti dovoljno da rasvetlimo posledice ovog sudara i da na taj način postavimo temelj objašnjenja koje naknadno može biti dalje teoretizovano i razvijano. Naime, jedna od odlika savremenog doba, koje pojedini autori smatraju dobom postistine (Peterson, i sur., 2018.), ogleda se u činjenici da je produkcija vesti i mišljenja postala „hidra sa mnogo glava (za svake novine koje umru rađa se 2000 novih blogova, facebook i twitter feed-ova!)“ (Harsin, 2105.:329), čime specijalizovani diskursi, kakav je i bezbednosni, gube na svojoj ekskluzivnosti i postaju znatno inkluzivniji tj. propusni za netradicionalne nosioce. Stručnjačke elite bivaju detronizovane, a ilokuciona kakofonija unutar diskursa dovodi do gubitka poverenja u njegove tradicionalne nosioce. U slučaju sekuritizacije, nepoverenje u ATL sekuritizatore čak poprima i dimenzije otvorenog animoziteta, pri čemu se političke elite najčešće percipiraju kao deo bezbednosne pretnje, a ponekad i kao sama pretnja. Poroznost granica diskursa, o kojoj govorimo, postala je moguća upravo zahvaljujući fenomenu virtuelno umreženog društva. Kako bi smo bolje razumeli ovu promenu potrebno je na kratko se osvrnuti na dva važna teorijska koncepta. Prvi je Castellsov koncept „masovne samokomunikacije“, a drugi je Foucaultov koncept kontrole diskursa primenom principa „proređivanja govornog subjekta“. Naime, kako primećuje Castells „transformacija komunikacijskog okruženja direktno utiče na oblike konstrukcije značenja, a samim tim i na proizvodnju odnosa moći“ (Kastels, 2018.:25). Castells ističe kako se poslednjih godina fundamentalna promena u sferi komunikacije ogleda u usponu onoga što on naziva „masovnom samokomunikacijom“, koja počiva na upotrebi interneta i bežičnih mreža kao platformi za digitalnu 
komunikaciju. Koncept masovne samokomunikacije, kako već samo ime otkriva, referiše na dve bitne karakteristike savremenog komuniciranja - masovnost i samostalnost. Ona je masovna jer „obrađuje poruke mnogih ka mnogima, može da dopre do mnoštva primalaca i da se poveže sa beskrajnim mrežama, koje prenose digitalizovane informacije kako u lokalu, tako i širom sveta" (Kastels, 2018.:25). S druge strane, ona je po svome karakteru samokomunikativna jer pošiljalac ,autonomno odlučuje o proizvodnji poruka, autonomno donosi odluku o primaocu poruke i preuzimanju poruke s komunikacionih mreža“" (Kastels, 2018.:25).

Vid komunikacije o kojoj govori Castells, naročito njegova samokomunikativna dimenzija, nužno mora dovesti do izmena mehanizama kontrole diskursa, o kojima govori Foucault (Fuko, 2019). Promeni je naročito podložan mehanizam koji ovaj filozof naziva „proređivanjem govornog subjekta“. Prema Foucaultu „niko neće ući u poredak diskursa ukoliko ne zadovolji izvesne zahteve ili ako nije, od početka, kvalifikovan za to" (Fuko, 2019.:25). On smatra da svako društvo određuje uslove primene diskursa i nameće izvestan broj pravila pojedincima koji ih kazuju, i na taj način ne dopušta svakome da im pristupi. Primera radi zdravstveni diskurs zahteva od svojih nosilaca stručnost u oblasti medicine, dok književni diskurs zahteva učešće pisaca ili kritičara. Prihvatanje određenog aktera kao legitimnog glasnogovornika određenog diskursa (u našem slučaju bezbednosnog) zavisi upravo od poštovanja ovog seta pravila. Međutim, uvođenjem masovne samokomunikacije u diskurzivnu jednačinu, dolazi do ozbiljne opstrukcije kako eksternih, tako i internih mehanizama kontrole diskursa (Fuko, 2019), a naročito do podrivanja principa proređivanja govornog subjekta. Masovna samokomunikacija, kako primećuje Castells, zasniva se na horizontalnim mrežama komunikacije koje elite teško mogu da kontrolišu i koje, zahvaljujući svojoj tehnološkoj platformi, čine mogućim „da neki društveni akter, pojedinačni ili kolektivni, izgradi svoju autonomiju u odnosu na institucije društva" (Kastels, 2018.:25). Autonomija pošiljaoca i recipijenta, kao glavna karakteristika komunkacije putem društvenih medija i mreža, podrazumeva potpunu samostalnost u postupku odabira željene publike i izboru između mnoštva poruka u virtuelnom prostoru. Na taj način, umesto da diskurs bude „proređen“ on se zapravo „zgrušava“, i postaje „prenaseljen“ sve većim brojem aktera, od kojih mnogi ne zadovoljavaju uslove o kojima je govorio Foucault. Ovo zgrušavanje, odnosno rapidno umnožavanje broja nosilaca bezbednosnog diskursa, ipak ne znači da se BTL sekuritizacije odvija bez svojih pravila, odnosno da ne poseduje sopstvene facilitating conditions, od kojih, baš kao i u slučaju ATL sekuritizacije, u mnogome zavisi uspeh čitavog procesa. O tome će biti više reči u nastavku ovog poglavlja, no pre nego što pređemo na pitanje unutrašnjih i spoljnih tj. ilokucionih $\mathrm{i}$ kontekstualni uslova uspešnosti BTL sekuritizacije, neophodno je rasvetliti još neke detalje u vezi sa pitanjem odnosa akter-publika koji čini okosnicu našeg koncepta.

Treba imati na umu pomenuto zgrušavanje govornih subjekata u bezbednosnom diskursu za posledicu ima svojevrsnu ilokucionu kakofoniju, koja, kako smo već pome- 
nuli, dovodi do gubitka poverenja u ATL sekuritizatore. Reč je o tome da se BTL sekuritizujući diskurs najčešće ne podudara sa ATL bezbednosnim diskursom, a da se unutar oba često mogu sresti „nesinhroni“ glasovi i dijametralno suprotne poruke. Pomenuti Wakefieldov slučaj, najslikovitiji je primer nesinhronizovanosti poruka među elitama, a različiti narativi koji se mogu uočiti unutar virtuelnog antivakserskog diskursa vrlo često su konfuzni, nedosledni i međusobno kontradiktorni. Upravo ovakvu situaciju mi nazivamo ilokucionom kakofonijom, i ona kao posledicu kod publike izaziva konfuziju, zebnju i strah. Ova osećanja možemo tumačiti kao osećaj ontološke nesigurnosti, jer ona sa sobom povlače gubitak poverenja u postojeći poredak, institucije društva i njegove autoritete, usled čega se građani, kao donedavno pasivna bezbednosna publika, odlučuju da brigu o vlastitoj bezbednosti uzmu u svoje ruke. Usled osećaja egzistencijalne ugroženosti, publika progovara jezikom bezbednosti i preduzima sekuritizujući čin, izvršivši tako pomenuto brisanje granice između aktera, publike i referentnog objekta bezbednosti. Publika de facto postaje sekuritizujući akter tj. BTL sekuritizator, koji upozorenje o egzistencijalnoj pretnji širi putem društvenih medija i mreža, sa namerom da za svoju sekuritizujuću agendu pridobije što veću podršku pripadnika ugrožene referentne grupe. Drugim rečima, BTL sekuritizacija podrazumeva građane u ulozi sekuritizujućeg aktera, koji se sekuritizujućom izjavom o ugroženosti određenog opšteg dobra, koje se tiče svih građana, obraćaju drugim građanima, u ulozi publike, zahtevajući od njih podršku i učešće u implementaciji mere neophodne za otklanjanje predočene pretnje.

Tvrdnju da bezbednosni diskurs koji nastaje na društvenim medijima i mrežama može poprimiti formu sekuritizujućeg čina, argumentovaćemo na primeru online aktivnosti antivakserskog pokreta u Republici Srbiji u narednom poglavlju. No, na ovom mestu neophodno je napomenuti da nije svaka bezbednosna poruka koja se može naći na internetu sekuritizujući čin. Naprotiv, veliki broj ovih iskaza mogao bi po svome sadržaju biti okarakterisan kao informativan ili analitički. Ova vrsta iskaza, uprkos nastojanju da deluje sugestivno prema donosiocima političkih odluka ili građanima (npr. brojni portali, blogovi ili komentari o međunarodnoj bezbednosti ili bezbednosti građana), zapravo ne poseduje pravu performativnu moć. Stoga BTL sekuritizujućim činom može biti smatran isključivo ilokucioni iskaz koji u potpunosti sledi strukturu ATL sekuritizujućeg iskaza tj. akcentuju ugroženost opstanka, prioritet preduzimanja akcije i scenario akcije ili najgori scenario, ukoliko akcija izostane (Buzan i sur., 1998.:24, 27, 32).

Baš kao i u slučaju ATL sekuritizacije, da bi BTL sekuritizujući čin bio uspešan on mora zadovoljiti određena unutrašnja ( $\mathrm{tj}$. ilokuciona) i spoljna (tj. kontekstualna) pravila. Drugim rečima, neophodno je da ispuni set facilitating conditions-a koji se u slučaju BTL sekuritizacije u velikoj meri razlikuje od onih koje je apostrofirala Kopenhaška škola. Kada je u pitanju interni kriterijum, on ostaje identičan - gramatika bezbednosti mora biti ispoštovana. Kako arhitektura sekuiritizujućeg iskaza, tako i 
specifični dijalekt ciljanog sektora. Međutim, gramatika bezbednosti sama po sebi i dalje ne garantuje uspešnost BTL sekuritizujućeg čina. Za njen uspeh neophodno je i zadovoljenje određenih eksternih uslova. U slučaju BTL sekuritizacije ti uslovi su bitno drugačiji nego kada je reč o izvornom teorijskom konceptu. Kako smo već rekli, ATL sekuritizacija za spoljne preduslove uspešnosti uzima autoritet i socijalni kapital sekuritizatora, kao i (relativnu) utemeljenost navodne pretnje. S druge strane, eksterni facilitating conditions BTL sekuritizacije vezani su za njenu viralnost i već pomenutu ilokucionu kakofoniju.

Dakle, prvi spoljni uslov je viralnost iskaza - što se brže i više sekuritizujući iskaz širi virtuelnom mrežom, to je njegov sekuritizujući efekat jači. Da bi iskaz postigao cilj on mora biti, u što kraćem roku od trenutka izgovaranja tj. postavljanja na društvenim medijima ili mrežama, pregledan, preuzet i podeljen od strane što većeg broja korisnika. Na taj način ovaj iskaz postaje viralan, kruži internetom i kao takav služi kao ulaznica u sekuritizujući diskurs. Važna odlika BTL sekuritizacije jeste da je ona, za razliku od svog starijeg ATL parnjaka, rezervisanog prvenstveno za elitu, inkluzivna za sve korisnike interneta. U BTL sekuritizujući diskurs pristupa jednostavnim shareom bezbednosnog iskaza. Ovaj iskaz u svetu digitalnih medija nije sveden isključivo na govorni čin, već obuhvata širu paletu audio-vizuelnih sadržaja i komunikacijskih praksi, ${ }^{9}$ onako kako to tvrde Williams i Macdonald (Williams, 2003.:512, 524-528; Macdonald, 2008.:568-570). Jednom kada korisnik podeli pomenuti iskaz/sadržaj on se „aktivira“ i iz uloge pasivnog posmatrača tj. publike, prelazi u ulogu sekuritizujućeg aktera.

Kako viralnost uvećava brojnost potencijalnih BTL sekuritizatora, njen uticaj na uspešnost čitavog procesa može biti upoređen sa značajem koji po ATL sekuritizaciju imaju autoritet i socijalni kapital elita. Međutim, dok ATL sekuritizujući akteri upravo na pomenutim elementima zasnivaju legitimitet nosioca bezbednosnog diskursa, BTL sekuritizacija legitimizirajući efekat ostvaruje na osnovu brojnosti aktera koji u njoj uzimaju učešće. Otuda BTL sekuritizatori sebe vide kao jedini legitimni tj. istinski vox populi.

Druga spoljna okolnost je ilokuciona kakofonija, o kojoj je već bilo dosta reči. Nju možemo sumirati kao prisustvo mnoštva nesinhronih sekuritizujućih glasova koji „zaglušuju“ i „delegitimišu“ ATL sekuritizatore i navode publiku da bezbednost uzme u sopstvene ruke. Što je na mreži veća povika o (ugroženoj) bezbednosti, to su veće šanse da BTL sekuritizacija uspe.

9 Tako na primer fenomen komunikacijske forme poznat pod nazivom meme u sebi sjedinjuje vizuelni i tekstualni sadržaj. Reč je o specifičnoj formi virtuelnog iskaza (memes se dele tj. share-ju isljučivo putem interneta) koja po svojoj strukturi predstavlja parafrazu maksime „slika govori više od hiljadu reči“. U slučaju meme-a, slika i reči kombinovani su tako da na najupečatljiviji način prenesu željenu poruku. 
Jedan od svakako najizazovnijih problema sa kojima se koncept koji mi predlažemo suočava jeste pitanje sprovođenja specijalne mere. Kako ATL sekuritizacija podrazumeva implementaciju vanredne mere, ili barem iniciranje javne debate koja će rezultirati pozitivnim odazivom publike u onoj meri koja je neophodna da bi se obezbedio legitimitet akcije, opravdano je postaviti pitanje sa kojim to delatnim potencijalom za sprovođenje specijalne mere nastupaju BTL sekuritizatori? Ukoliko, kako smo prethodno naznačili, BTL sekuritizacije kreće „odozdo“ tj. iz krugova „aktivirane“ publike koju čini virtuelno umreženog građanstvo, to znači da su BTL sekuritizatori lišeni mogućnosti direktnog pristupa monopolu sile. Bez monopola sile nema instrumenta realizacije, odnosno garancije da će specijalna mera biti izvršena. Samim time, sledstveno logici ATL sekuritizacije, proces nije moguće uspešno privesti kraju.

Ovaj problem nije toliko teško prevazići, koliko se to možda na prvi pogled čini. Najlakše rešenje podrazumeva pozivanje na argument prema kome BTL sekurtizirajući čin deluje kao pritisak „odozdo prema gore“ tj. kao pritisak koji, ukoliko je dovoljno viralan tj. rasprostranjen, može naterati ATL sekuritizatore (koji raspolažu autoritetom, socijalnim kapitalom i monopolom sile) da sprovedu specijalnu meru i tako izađu u susret građanima. Ovakvo rešenje bi se u određenoj meri poklopilo sa Vuorijevim konceptom multivarijetetne sekuritizacije, koja ne podrazumeva samo uvođenje specijalne mere, već može služiti i različitim političkim ciljevima među kojima je i „uveravanje donosilaca odluka o hitnosti pretnje, kako bi to pitanje oni stavili na dnevni red i potom realizovali predložene mere" (Vuori, 2008.: 77). Međutim, najlakše rešenje nije uvek i ono pravo. Za nas ovakva argumentacija nije prihvatljiva s obzirom na to da bi se njome proces BTL sekuritizacije redukovao na prostu inverziju uloga sekuritizujućeg aktera i publike. Građani bi postali akteri tj. izvršitelji ilokucijskog čina, tradicionalni sekuritizatori publika, dok bi se perlokucijski efekat sveo na spremnost države da sprovede zahtevanu specijalnu meru. Drugim rečima, BTL sekuritizacija bi bila spuštena na nivo građanskog aktivizma kojim online javno mnjenje vrši pritisak na vladajuće elite. Naš koncept podrazumeva znatno više od toga. Mi tvrdimo da virtuelno umreženi građani poseduju mogućnost da na sebi svojstven način sprovedu specijalnu meru, što je naročito vidljivo na polju zdravstvene bezbednosti. Ta mera se realizuje se kroz udruženi individualni otpor merama imunizacije koje u ime države propisuju zvanični zdravstveni autoriteti. U slučaju antivakserskog pokreta, odbijanje obavezne ili preporučene vakcinacije predstavlja „bezbednosnu“ akciju koja remeti ustaljen poredak stvari. Dakle, odbijanje vakcine jeste specijalna mera koja, iako prepuštena svakom pojedincu ponaosob, predstavlja direktnu posledicu BTL sekuritzirajućeg diskursa i stoga se može razumeti kao kolektivna specijalna mera.

Iz svega prethodno rečenog proizilazi da bi smo BTL sekuritizaciju mogli definisati kao oblik sekuritizacije u kome publika, sačinjena od digitalno umreženih građana, posredstvom društvenih medija i mreža, osporava elitama ulogu sekuritizatora i njene prerogative prisvaja za sebe. Prostor za pojavu novih sekuritizujući aktera, onih izvan krugova državocentričnih elita, ostavljaju i Buzan, Waever i De Wilde, priznajući da 
se bezbednost ne tiče samo države, već da je ona polje na kome se, za poziciju nosioca sekuritizacije, može takmičiti više aktera (Buzan i sur., 1997.:37). Uprkos tome, ovi autori smatraju da država ostaje idelani sekuritizator, usled duge istorije vršenja bezbednosnih dužnosti i činjenice da je „najadekvatnije strukturirana za tu svrhu“ (Buzan i sur., 1997.:37). Ipak, nešto više od dve decenije nakon postavljanja ove „dijagnoze“, svedoci smo razvoja nove, virtulne strukture, koja sve više uzdrmava tradicionalne obrasce raspodele moći, a samim time i državnocentrični ekskluzivitet sekuritizacije.

\section{BTL sekuritizacija u Republici Srbiji u doba pandemije COVID-19}

Istorija antivakcionog pokreta u Srbiji sa pravom se može podeliti na period pre i posle Wakefielda. Radovanović navodi da iako su se zbog Lübeck incidenta ${ }^{10}$ prvi otpori vakcinisanju javili 1947. godine, oni zbog tadašnjeg jugoslovenskog autoritarnog režima nisu bili uspešni (Radovanović, 2017.:2). Tek nakon objavljivanja Wakefieldovog rada i pojave društvenih medija i mreža, ovi pokreti počinju da se razvijaju i jačaju. Do 2011. godine obuhvat MMR vakcinacije u Srbiji bilo je iznad 95\%, da bi pod uticajem antivakserskog pokreta, 2014. godine pao na 85,6\%, što je dovelo do 605 prijavljenih slučajeva malih boginja početkom 2015. godine (Stokić Pejin, 2016.). Stoga je 2015. i 2016. godine srpski parlament usvojio nove zakone sa većim kaznama za roditelje koji odbijaju da vakcinišu decu, kao i zabranama upisa u vrtiće i osnovne škole ukoliko deca nisu vakcinisana. Uvođenje kazni dovelo je do protesta antivakserskog pokreta u nekoliko gradova u Srbiji, u maju 2015. i martu 2016. godine. Ove proteste je organizovao pokret Građanska inicijative za neobaveznu vakcinaciju, ${ }^{11}$ čiju facebook stranicu „Vakcine INFO“ prati 32.500 ljudi. $^{12}$

Prema podacima Instituta za javno zdravlje Srbije - Batut, u periodu od oktobra 2017. do avgusta 2019. godine na teritoriji Republike Srbije (uključujući i teritoriju nadležnosti Zavoda za javno zdravlje Kosovska Mitrovica), registrovano je ukupno 5798 slučajeva malih boginja, od čega je 15 okončano smrtnim ishodom usled komplikacija. U pitanju su prvi smrtni slučajevi uzrokovani ovim virusom nakon 20 godina. Navodi se da je 94\% obolelih osoba bilo nevakcinisano, nepotpuno vakcinisano ili nepoznatog vakcinalnog statusa (Institut za javno zdravlje Srbije „Dr Milan Jovanović Batut" [IZJZS-Batut], 2019.).

\footnotetext{
10 Prilikom incidenta koj će kasnije postati poznat kao „Lübeck katstrofa“, 251 novorođenče primilo je tri oralne doze nove Bacille Calmette - Guérin (BCG) antituberculosis (TB) vakcine, zaražene virusom tuberkuloze. Od pomenutog broja 173 dece razvilo je kliničke ili radiološke znake infekcije ali je preživelo, dok je 72 umrlo (Fox i sur, 2016.:1).

11 Pored pomenutih protesta, ova organizacija je 2016. organizovala i prvu antivaksersku konferenciju u regionu, pod nazivom "(Ne)opravdanost prisilne vakcinacije, medicinsko-etički, pravno-politički aspekti”.

12 Pregledano 6. oktobra 2020.
} 
Rezultati UNICEF-ovog istraživanja Tracking Anti Vaccination Sentiment in Eastern European Social Media Networks, potvrđuju da u regionu Istočne Evrope sve veći uticaj na odluku o (ne)vakcinisanju imaju društvene mreže (UNICEF, 2013.). Ovo istraživanje ukazuje i na centralnu ulogu koju u formiranju antivakserskih stavova i širenju dezinformacija imaju istaknuti pojedinci tj. tzv. influnencer-i. Tako je npr. početak intenzivnije delatnosti antivakserskog pokreta u Srbiji, ali i regionu, obeležila Slađana Velkov, koja među istomišljenicima uživa status „antivakserske ikone Balkana“ (Radovanović, 2017.:4). Među njenim tvrdnjama nalaze se sledeće: epidemija svinjskog gripa je lažna, a u vakcini protiv svinjskog gripa otkriven je smrtonosni virus ptičjeg gripa, vakcinacija dovodi do sterilizacije i teških oboljenja, vakcinacija nije iskorenila niti jednu bolest, vakcinacija usmrtila i osakatila bezbroj dece (Katalinić, 2014.); vakcine su biološko oružje, autističnu decu treba tretirati toksičnim hlorin dioksidom (Radovanović, 2017.:4). Pored Slađane Velkov, veliki ugled uživa i nedavno preminuli kontoroverzni srpski stomatolog Todor Jovanović, široj javnosti poznat po tvrdnji da je „izumeo“ lek za AIDS (Radovanović, 2017.:5), a njegovi intervjui i gostovanja na društvenim medijima imaju po nekoliko desetina hiljada pregleda. Još jedna od „zvezdi“ srpskog antivakserskog neba je i psihijatar dr Jovana Stojković, koja se predstavlja kao borac protiv obavezne vakcinacije i farmaceutske mafije. U intervjuu "Vakcine predstavljaju najveću opasnost za našu decu" dr Stojković iznela je tvrdnje da je zarazne bolesti poput malih boginja bolje preležati jer na taj način osoba fizički i psihički ojačava, te da zbog vakcina mi umesto zaraznih bolesti danas imamo autoimune bolesti, hronične bolesti dece, autizam, leukemiju i ostale vrste kancera. ${ }^{13} \mathrm{Tu}$ su naravno i drugi istaknuti antivakserski aktivisti koji, iako ne potiču iz miljea zdravstvene zajednice, uživaju autoritet „znalaca“ zahvaljujući svom statusu javne ličnosti, poput dramaturškinje Maje Volk, folk pevačice Jelene Karleuše ili tenisera Novaka Đokovića.

Nakon proglašenja svetske pandemije virusom COVID-19, a naročito tokom trajanja i po okončanju vanrednog stanja u Srbiji, uvedenog nekoliko dana kasnije, ${ }^{14}$ došlo je do intenziviranja antivakserskog diskursa na društvenim medijima i mrežama. Tako je npr. pomenuta dr Stojković redovno na svom YouTube kanalu postavljala video materijale posvećene borbi protiv zdravstvenih mera i društvenih restrikcija koje je u cilju zaustavljanja zaraze propisao Krizni štab vlade Republike Srbije. U video obraćanju iz aprila 2020 godine, koji se odnosi na vakcinu protiv COVID-19, ona postojeću pandemiju naziva "panikdemijom“ iza koje stoji Bill Gates - glavni kreator svetskog javnog zdravlja. ${ }^{15} \mathrm{U}$ ovom videu, koji je odmah po objavljivanju postao viralan (za prve

13 Balkan Info „Intervju”. Jovana Stojković - Vakcine predstavljaju najveću opasnost za našu decu! Pregledano 6. oktobra 2020. (https://www.youtube.com/watch?v=GWNJeGwgGKA)

${ }^{14}$ Svetska zdravstvena organizacija proglasila je globalnu pandemiju 11. marta, dok je vanredno stanje u Republici Srbiji uvedeno 15. marta. Dva dana kasnije na snagu je stupila i mera policijskog časa, a ubrzo potom proglašena je i epidemija od većeg epidemiološkog značaja.

15 Pokret živim za Srbiju dr Jovana Stojković. Vaistinu vakciNACIja. Pregledano 6. oktobra 2020. (https://www.youtube.com/watch?v=simzoI fL74) 
dve nedelje imao je više od 61.000 pregleda), dr Stojković poziva na otpor obaveznoj i zalaže se isključivo za praksu dobrovoljne vakcinaciju u borbi protiv COVID-19. Interesantan je i primer konferencije za štampu koju je 29. aprila 2020, u holu Narodne skupštine Republike Srbije, održala narodna poslanica i lekarka prof. dr Nada Kostić, još jedno ime sa spiska boraca protiv obavezne vakcinacije. Tokom ovog obraćanja dr Kostić je iznela niz senzacionalističkih tvrdnji - od toga da je virus COVID-19 veštački stvoren i da su njegovi tvorci George Shoros i Bill Gates, preko toga da je pandemija zapravo paravan za zaveru koja treba da omogući globalno instaliranje $5 \mathrm{G}$ mreže, pa sve do tvrdnje da ono što izaziva smrtnost nije virus, već upravo $5 \mathrm{G}$ mreža koja oduzima kiseonik. ${ }^{16}$

Osim pomenutih istaknutih pojedinaca, na društvenim mrežama deluju i brojne grupe građana usmerene na borbu protiv obavezne vakcinacije. Od trenutka izbijanja pandemije COVID-19, dominantan narativ koji putem svojih post-ova i share-ova kreiraju njihovi članovi, može se okarakterisati kao teoretisanje o zaveri u čijem centru se najčešće nalaze Bill Gates i $5 \mathrm{G}$ mreža. Tako na je primer, na društvenoj mreži Facebook aktivan veći broj ovakvih grupa, od kojih ćemo pomenuti samo one uticajnije tj. one čije članstvo broji više od 1000 članova: „Vakcinacija i sloboda izbora/Vaccine Freedom of Choice“, „Stop obaveznoj vakcinaciji u Srbiji“, „Pravo na prirodnu imunizaciju i neobavezno špricanje imuno preparatima“ i „Stop prisilnoj KORONA vakcinaciji i globalizaciji“. Od navedenih grupa čak tri su javne (public), što znači da je pristup njihovim facebook stranicama slobodan i otvoren za javnost. Grupa „Stop prisilnoj obaveznoj vakcinaciji u Srbiji“ zatvorenog je tipa (private), i da bi joj se pristupilo neophodno je da zahtev za članstvo bude odobren od strane administratora grupe. Pored toga što razmenjuju najnovije ,informacije“ o virusu, planovima za vakcinaciju i štetnim efektima vakcine, članovi ovih grupa u svojim postovima daju podršku istaknutim antivakserima poput dr Stojković ili Novaka Đokovića.

U nastavku poglavlja, analizom aktivnosti koje su srpski antivakseri preduzimali neposredno pre, i nakon proglašenja globalne COVID-19 pandemije, proverićemo našu tezu o online antivakcionom diskursu kao primeru horizontalne tj. BTL sekuritizacije. Kako bi smo to učinili na što precizniji način, naša argumentacija slediće strukturu izlaganja koju smo primenili prilikom upoznavanja sa ključnim karakteristikama ATL i BTL sekuritizacije.

Prvo pitanje kojim se moramo pozabaviti jeste uloga istaknutih antivaksera tj. influencer-a u procesu BTL sekuritizacije. Pomenuto UNICEF-ovo istraživanje pridaje veliki značaj ovim pojedincima i smešta ih u centar procesa širenja dezinformacija i stvaranja

16 СРБИН.инфо. Skupština - ovo se krije od naroda: Doktorka Kostić otkrila pravu istinu o virusu. Pregledano 6. oktobra 2020. (https://www.youtube.com/watch?v=8LtEAjXKv5U\&ab channel=\%D0\% A1\%D0\%A0\%D0\%91\%D0\%98\%D0\%9D.\%D0\%B8\%D0\%BD\%D1\%84\%D0\%BE) 
javnog odijuma prema vakcinama. Ono što antivakserske „ikone“ čini tako važnim je to što one „dodaju svoju ličnu interpretaciju medijskim sadržajima i prenose ih dalje na svoju publiku" (UNICEF, 2013.:8). Međutim, iako su neosporno veoma značajni kao kreatori i „skretničari“ antivakcionog diskursa, bilo bi pogrešno ove influncer-e označiti kao pokretače i nosioce BTL sekuritizacije. Njihovu ulogu treba tumačiti isključivo u spirtus movens kontekstu, te im nikako ne treba pripisivati svojstvo pojedinačnih sekuritizatora. Naime, kako je već rečeno, da bi sekuritizujući iskaz prerastao u BTL sekuritizujući čin, on mora postati viralan tj. pregledan, preuzet, podeljen i komentarisan od strane što većeg broja korisnika društvenih medija i mreža. Bez toga, njegov obuhvat će ostati relativno sužen, a mobilizacija publike u sekuritizujući diskurs, to jest njena „regrutacija“ i prevođenje u ulogu skuritizatora, doživeće neuspeh. Tako je na primer, pomenuto konferencijsko obraćanje dr Nade Kostić naišlo na nedovoljno interesovanje mainstream medija u Republici Srbiji, ali je zato njegov snimak, koji je postavljen na YouTube-u, podeljen od strane brojnih internet portala, kao i od strane korisnika društvenih mreža poput Twittera i Facebooka. Takođe, ovaj video zapis postao je obavezno „štivo“ za informisanje i na pomenutim antivakserskim facebook grupama. Isto važi i za javni angažman dr Jovane Stojković, koja svoju borbu za slobodu izbora prilikom vakcinacije vodi dominantno putem svog YouTube kanala, twitter naloga, ličnog facebook profila i facebook stranice pokreta Živim za Srbiju, na čijem čelu se nalazi. S obzirom da uticajni antivakseri poput dr Stojković imaju ograničen pristup sredstvima ATL komunikacije, oni su prinuđeni da se okrenu online komuniciranju sa publikom. No, bez obzira na snagu i prijemčivost njegove poruke, pojedinac per se ne može odigrati ulogu sekuritizatora. U ATL sekuritizaciji neophodni su mu status i instrumenti koji spadaju u prerogative državne vlasti, dok mu je u slučaju BTL sekuritizacije neophodna zajednička akcija. Naime, tek u interakciji sa publikom tj. angažovanjem potonje u deljenu, komentarisanju i "nadograđivanju“ poruke ličnim stavovima interpretacijama korisnika društvenih medija i mreža, „omasovljen“ pojedinačan iskaz može prerasti u sekuritizujući čin. To se dešava onoga trenutka kada publika usvoji upozorenje o pretnji koju predstavljaju vakcine i počne da, putem virtuelne mreže, deli poziv na sprovođenje specijalne mere tj. pružanje otpora vakcinama i vakcinisanju. Jednostavno rečeno, BTL sekuritizujući čin je načinjen je tek onda kada publika i sama postane sekuritzator.

Kada je u pitanju diskurs srpskih antivaksera on u potpunosti sledi „propisanu“ arhitekturu bezbednosnog iskaza. Njihovi post-ovi i share-ovi na društvenim mrežama usmereni su na to da rečju i slikom dočaraju svu težinu pretnje koju vakcine predstavljaju ne samo za njih i njihove bližnje, već i po egzistenciju čitavog srpskog naroda, a često i celog čovečanstva. Pored neposredne štetnosti vakcine, često se u prvi plan ističu i prikrivene namere svetskih moćnika i „vladara iz senke“, koji COVID-19 vakcinom planiraju da redukuju ili čipuju svetsku populaciju, a neretko se u njihovim objavama podiže glas upozorenja i o predstojećem oduzimanju dece svima koji budu odbili da ih vakcinišu. Sastavni deo ovog diskursa je i antagonizacija države, državnih 
zvaničnika i zvaničnih mera za suzbijanje pandemije, ${ }^{17}$ dok su zdravstvene elite po pravilu predstavljene kao saučesnici svetskih tajkuna, farmakomafije ili globalista. Kao primer diskursa koji sadrži većinu od pomenutih elemenata može biti navedena pomenuta facebook stranica „Stop prisilnoj KORONA vakcinaciji i globalizaciji!!“", na kojoj se mogu naći sledeće informacije o ciljevima i aktivnostima grupe: „Ova grupa nastala je kao izraz potrebe da se borimo protiv obavezne vakcine protiv koronavirusa, koja je već smućkana i uskoro će biti u upotrebi, iako nije čak ni testirana na životinjama, mada je to dosad bilo pravilo. O vakcini govore globalističke vođe i tajkuni poput Bila Gejtsa, koji finansira Svetsku zdravstvenu organizaciju, i koji namerava da ostvari ogromnu zaradu od vakcinacije preko sedam milijardi ljudi, kao i domaći farmakolobisti kao što su Predrag Kon i Darija Kisić Tepavčević, inače članovi Rotari kluba, koji finansira Bil Gejts. Da će vakcina biti obavezna, rekao je i Ivica Dačić, a da se može sprovoditi i prisilno, uz pomoć vojske i policije, to kaže Zakon o zaštiti stanovništtva od zaraznih bolesti. Udružimo se i spasimo se od ovog zla! Jer, kao što je rekao Gejts, sledeći korak je čipovanje!“. ${ }^{18}$ Nije teško primetiti kako ovaj mali „informator“, napisan u formi apela za buđenje, u potpunosti sledi pomenuti Buzanov princip dvostrukog predviđanja (Buzan i sur., 1998.:32). U njemu su prisutna oba scenarija vezana za realizaciju specijalne mere - onaj koji anticipira posledice njenog izostanka i onaj koji predviđa dalja dešavanja ukoliko do njene primene dođe. U prvom posledice se kreću u rasponu od „ogromne zarade“ koju će na račun naroda ostvariti kriminalizovani ATL sekuritizatori (globalisti, svetski tajkuni i njihovi lokalni eksponenti - srpski epidemiolozi Predrag Kon i Darija Kisić Tepavčević, kao i potpredsednik srpske vlade i ministar spoljnih poslova Ivica Dačić), pa sve do čipovanja ljudi u režiji Bill Gates-a. Drugi, pak predviđa „spasenje od zla“ koje je moguće samo kroz zajedničku akciju tj. otpor obaveznoj vakcinaciji.

Pored toga što dosledno prati strukturu bezbednosnog argumenta, srpski antivakserski diskurs precizno pogađa i bezbednosni dijalekt karakterističan za ciljani sektor bezbednosti. Iako su Buzan; Waever i de Wilde zdravstvenu bezbednost stavili u domen sektora životne sredine (Buzan i sur.: 1998.:75), koji akcenat stavlja na interakciju

${ }^{17} \mathrm{Na}$ ovom mestu je neophodno naglasiti kako izmeštanje težišsta egzistencijalne pretnje sa pandemije na sekuritizatore i mere prevencije nipošto ne treba tumačiti kao desekuritizaciju pomenutih zdravstvenih pretnji. Kako smo već istakli, prema izvornoj Waeverovoj zamisli, desekuritizacija podrazumeva „pomeranje problema iz vanrednog režima u uobičajeni proces pregovaranje u političkoj sferi“" (Buzan i sur., 1998.:4). To svako ne može biti slučaj sa antivakserima, jer u njihovim očima pitanje bolesti i dalje ostaje u sferi bezbednosti, no ono je kao takvo uklopljeno u kontekst znatno veće i kompleksnije egzistencijalne pretnje (npr. pomenute tvrdnje dr Kostić o svetskoj zaveri i veštački stvorenom virusu). Istina, određene paralele bi se mogle povući sa tzv. desekuritizacijom putem zamene (replacement) o kojoj govori Lene Hansen, no bez obzira na određene sličnosti sa ovim konceptom, koji podrazumeva zamenu jedne pretnje drugom, po pravilu „opasnijom“ (Hansen, 2012.:541), BTL sekuritizacija ne gravitira vraćanju pitanja u regularne političke tokove, već naprotiv, za konačno ishodište ima konstituisanje sopstvene specijalne mere.

18

Pregledano 3. oktobra 2020. 
društva i prirodnog okruženja, anivakserski pokret svojim sekuritizujućim diskursom obuhvata i ključne pojmove socijetalnog i političkog sektora. Tako srpski antivakseri, osim što potenciraju narativ o vakcinaciji kao neprirodnom ili protivprirodnom činu, ${ }^{19}$ takođe akcentuju identitetski deo problema, stavljajući u prvi plan, pored ugroženosti sopstvenog zdravlja i zdravlja bližnjih (najčešće dece), ugroženost srpskog tradicionalnog ethos-a. Takođe, praksa vakcinacije, naročito obavezna, često se tumači i kao sastavni deo zavere kojom globalisti nastoje da podriju suverenitet nacionalnih država.

Objedinjavanjem arhitekture bezbednosnog iskaza i dijalekta bezbednosti srpski antivakseri zadovoljavaju kriterijum poštovanja gramatike bezbednosti, čime je ispunjen prvi tj. interni facilitating conditions BTL sekuritizacije. Kada je u pitanju viralnost kao eksterni uslov, već smo videli da antivakseri na društvenim medijima mrežama lako privlače pažnju online publike. Njihove objave veoma brzo postaju viralne, a nakon toga poseduju i svojstvo repetativnosti. Veoma je čest slučaj da nakon nekog vremena od prvog talasa širenja određenog sadržaja, isti iznova bude deljen od strane antivakserske zajednice čime se aktuelnost i domet date objave prolongira i uvećava. Veliki broj pratilaca antivakserskih „ikona“ tj. influencer-a, kao i brojno članstvo antivakserskih grupa na društvenim mrežama, svedoči o snažnom viralnom potencijalu koji poseduju ovi sadržaji. Ilustracije radi facebook profil Slađane Velkov ima 4999 prijatelja, prati ga još 49.423 ljudi, dok njenu profesionalnu stranicu na istoj mreži prati 36.778 ljudi. ${ }^{20}$ Zvanična facebook stranica dr Jovane Stojković ima 26.896 sviđanja (like) i 29.668 pratilaca, njen pokret Živim za Srbiju na svojoj stranici beleži 4117 sviđanja i 4310 pratilaca, dok njen YouTube kanal ima više od 16.000 pratilaca (subscriber-a). ${ }^{21}$ Facebook grupe „Stop obaveznoj vakcinaciji u Srbiji“ i „Stop prisilnoj KORONA vakcinaciji i globalizaciji“ imaju po 8.800 članova, grupa „Vakcinacija i sloboda izbora/ Vaccine Freedom of Choice“ ima 5.682 člana, dok grupa „Pravo na prirodnu imunizaciju i neobavezno špricanje imuno preparatima“ ima 1300 članova. ${ }^{22} \mathrm{Na}$ umu treba imati i činjenicu da pratioci i članovi ovih grupa sadržaje usmerene protiv vakcina i zvaničnih mera za suzbijanje pandemije COVID-19 ne plasiraju samo unutar kruga svojih istomišljenika tj. pomenutih grupa, već da ih često dele i na svojim privatnim profilima i nalozima na društvenim mrežama.

19 Tako se npr. na pomenutim facebook stranicama često deli video zapis intervjua u kome dr Stephanie Seneff, kontroverzna istraživačica sa Masačusetskog instituta za tehnologiju (MIT), tvrdi kako je vakcinacija protiv gripa ili bilo koga virusa protivprirodna i da uzrokuje poremećaje i bolesti u vakcinisanim populacijama. Ovaj intervju se može naći na YouTube-u pod nazivom Vakcine izazivaju autizam - Dr Stephanie Seneff. Pregledano 3. oktobra 2020. (https://www.youtube.com/watch?v=zZH67H8wUVw\&t=226s)

20 Pregledano 3. oktobra 2020.

21 Pregledano 3. oktobra 2020.

22 Pregledano 3. oktobra 2020. 
Drugi eksterni uslov - ilokuciona kakofonija, takođe je zadovoljen. U slučaju aktivnosti srpskog antivakcionog pokreta evidentno je razmimoilaženje između ATL i BTL bezbednosnog diskursa, naročito od izbijanja aktuelne pandemije. Dok ATL sekuritizatori (državni zvaničnici i krizni štab) insistiraju na poštovanju vanrednih mera i zdravstvenih preporuka, iznoseći argumente u prilog buduće vakcinacije protiv COVID-19, BTL sekuritizatori osporavaju gotovo sve preduzete mere zaštite i suzbijanja virusa - od preporuke socijalne distance i zabrane javnih okupljanja, do nošenja zaštitnih maski, i pritom pozivaju građane na bojkot vakcine koja je u pripremi. Na ovom mestu treba istaći da je, tokom prvih meseci globalnog širenja virusa, a posebno u periodu neposredno pre proglašenja vanrednog stanja, na ilokucionu kakofoniju u Srbiji značajno uticao nesklad u izjavama ATL sekuritizatora. Tako su npr. na konferenciji za štampu, održanoj u zgradi Predsedništva Republike Srbije, 26. februara 2020, predstavnici države i medicinske struke pokušali da relativizuje zdravstveni rizik predstojeće pandemije i umanje paniku koja se ubrzano širila među građanima. Tom prilikom se moglo čuti da je reč o „najsmešnijem virusu na svetu“, nečemu „mnogo slabijem od gripa“ i da je upala pluća najveća komplikacija koju COVID-19 može izazvati (Milutinović, 2020.:250). Međutim, nepunih petnaest dana kasnije, državni zvaničnici i medicinski ekspertski tim, preuzeli su ulogu sekuritizatora, a njihov narativ doživljava iznenadni zaokret i biva usmeren ka apostrofiranju pretnje i opasnosti od predstojeće zdravstvene katastrofe. Na taj način je zvanični diskurs, za nesrazmerno kratko vreme, preveden iz diskursa negacije pretnje u diskurs njene sekuritizacije, čime je u velikoj meri kompromitovan u očima javnosti. Pad poverenja u ATL sekuritizatore nastavljen je tokom i po okončanju vanrednog stanja (VALICON, 2020.: 1), umnogome potaknut brojnim nedoslednostima prisutnim u izjavama Kriznog štaba, kao i međusobno protivrečnim stavovima njegovih članova (Milutinović, 2020.:252-253, 257). Ovako kreirana ilokuciona kakofonija dodatno je pojačana senzacionalističkim izveštavanjem tabloidnih listova i njihovih internet portala (Istinomer, 2020.), što je rezultiralo pomenutim fenomenom „zgrušavanja govornog subjekata“, i ulaskom sve većeg broja građana u horizontalni sekuritizujući diskurs, koji je sve manje bio usmeren na virus i pandemiju, a sve više na ATL sekuritizatore.

Tako dolazimo i do pitanja realizacije specijalne mere, koja u „kanonskom“ konceptu sekuritizacije predstavlja konačno merilo njene uspešnosti. Kako smo već istakli, specijalna mera pretpostavljena našim konceptom ne može imati intenzitet i (sve)obuhvat nalik onome koji odlikuje specijalne mere sprovedene od strane države. U odsustvu monopola sile, građani kao BTL sekuritizatori raspolažu isključivo individualnim merama koje svoj puni sekuritizacijski potencijal postižu isključivo kroz združenu akciju, u našem slučaju - kroz otpor vakcinama i socijalno restriktivnim merama zdravstvene zaštite. Konačni ishod srpske antivakserske BTL sekuritizacije, biće poznat onoga trenutka kada vakcina protiv COVID-19 postane svakodnevica. Ukoliko dođe do značajnijeg otpora vakcinaciji, naročito ukoliko ona bude obavezna, ili obavezujuća za određene slojeve stanovništva, to će značiti da je sekuritizacija urodila plodom. Takođe, to 
će neminovno biti uvod u intenzivniju konfrontaciju između ATL i BTL sekuritizatora, koja može eskalirati građanskim nemirima kakve smo u Srbiji videli početkom jula $2020 .{ }^{23}$ Ovi nemiri, nastali kao reakcija na najavu ponovnog zaoštravanja restriktivnih mera usled naglog rasta broja zaraženih neposredno nakon okončanja vanrednog stanja, već su sami po sebi nagoveštaj mogućeg uspeha antivakserske BTL sekuritizacije, jer je država, pod pritiskom protesta, ubrzo odustala od reaktualizacije pomenutih mera. No, priča o julskim protestima je znatno kompleksnija, s obzirom na to da oni nisu bili motivisani isključivo rezigniranošću građana načinom na koji se država bori protiv pandemije, već su generisali šire građansko nezadovoljstvo različitim aspektima vladavine aktuelnog političkog režima. Stoga se ovi protesti mogu posmatrati i kao eskalacija duže vreme prisutnog online aktivizma protesnog tipa (Petrović, 2016.:424), te njihov uspeh i odvraćanje ATL sekuritizatora od uvođenja strožih anti-COVID-19 mera ne sme biti pripisan isključivo antivakserima, ${ }^{24}$ iako je njihovo prisustvo na demonstracijama bilo više nego evidentno. Samim time, ovaj slučaj nećemo posmatrati kao merilo uspešnosti BTL sekuritizacije. Tek sa dešavanjima koja će uslediti nakon što vakcina protiv COVID-19 bude puštena u širi opticaj, moći ćemo da donesemo sud o uspešnosti, ne samo srpske, već i antivakserske BTL sekuritizacije širom sveta.

\section{Zaključak}

U poslednjih nekoliko godina posledice delovanja antivakserksog pokreta (uočljiv rast broja obolelih od virusa morbila u Evropi i SAD) jasno ukazuju na to da je eksluzivitet države kao nosioca zdravstvene sekuritizacije u velikoj meri ugrožen ilokucionom kakofonijom koja je omogućila netradicionalnim akterima pristup sekuritizujućem diskursu. To u mnogome potvrđuje našu polaznu obzervaciju o tome kako su promene u praksi društvenog, političkog i bezbednosnog komuniciranja, inicirane naglim uzletom digitalnih društvenih medija i mreža, proizvele promenu ustaljenih pravila sekuritizujuće igre. Primer antivakserske BTL sekuritizacije do koje je u Republici Srbiji došlo nakon pandemije COVID-19, slikovito pokazuje kako se ta promena ne ogleda isključivo u osporavanju skuritizujućeg autoriteta političkih vlasti, već i u nastojanju građana da sekuritizuju upravo ATL sekuritizatore tj. da državu i njene stručnjačke

23 Protesti su otpočeli 7. jula u kasnim poslepodnevnim časovima u Beogradu, spontanim okupljanjem nekoliko hiljada građana ispred zgrade Narodne Skupštine, po završetku konferencije za štampu, na kojoj je predsednik Republike Srbije, Aleksandar Vučić, najavio zabranu okupljanja za više od pet ljudi na javnim mestima i ponovno uvođenje zabrane kretanja tj. policijskog časa. Tokom večeri, demonstracije su prerasle u oštre sukobe građana i policije. Građani su nastavili sa okupljanjima i narednih dana, a protesti su se, u manjem obimu, prelili i na druge gradove u Srbiji - Novi Sad, Niš, Zrenjanin i Kruševac. Najavljena mera policijskog časa nije uvedena, a protesti su nakon pet-šest dana počeli da gube na brojnosti i intenzitetu.

${ }^{24}$ Kao adekvatnija ilustracija masovnog otpora uvođenju novih restriktivnih mera u borbi protiv pandemije, po modelu BTL sekuritizacije, može poslužiti primer nedavnih demonstracija u Berlinu i Londonu, koje su organizovali tzv. korona-skeptici, antivakseri i borci protiv 5G mreže (Gayle i Blackall, 2020.). 
elite označe kao pretnju sopstvenoj egzistenciji. S obzirom na to da BTL sekuritizacija ne dolazi „odozgo“ tj. da nije inicirana od strane elita koncentrisanih oko državocentričnih izvora moći, već da su njeni inicijatori građani, reč je o novom bezbednosnom fenomenu koji zaslužuje da bude podrobnije ispitan.

Mi smo na prethodnim stranicama ponudili teorijski okvir na osnovu koga bi bilo moguće sprovesti dalja istraživanja. Prvo smo, povlačenjem razlike između vertikalne, ATL sekuritizacije, utemeljene na konceptualnoj distinkciji između aktera i publike, i horizontalne, BTL sekuritizacije, u kojoj se granice između aktera, publike i referentnog objekta brišu, obrazložili polaznu tezu o promeni savremene bezbednosne pardigme. Potom smo detaljno razradili teorijski model, koji podrazumeva precizno opisan i objašnjen modus operandi BTL sekuritizacije. U radu je shodno tome obrazložen način na koji se online bezbednosni diskurs pretvara u BTL sekuritizujući čin, kao i način na koji inkluzivnost ovog diskursa izmešta građane iz uloge publike u ulogu sekuritizujućeg aktera. Takođe, veliku pažnju posvetili smo unutrašnjim i kontekstualnim uslovima uspeha BTL sekuritizujućeg čina, tj. konstituisanju novog seta facilitating conditions-a (bezbednosna gramatika, viralnost i ilokuciona kakofonija), adekvatnog za objašnjenje horizontalne sekuritizacije prisutne na internetu. Valjanost modela testirali smo na primeru online aktivnosti pomenutog antivakserskog pokreta. Prezentovani model ostaje otvoren za dalje dorade i kritike, naročito u onim segmentima koji se tiču perspektiva za BTL implementaciju specijalne mere. No, kako je već napomenuto, za nove i preciznije uvide u ovaj deo problema moraćemo sačekati širu upotrebu vakcine protiv COVID-19, kao i antivaksersku reakciju koja će potom uslediti.

\section{Literatura}

1. Austin, J. L. (1962). How to Do Things with Words. London: Oxford University Press.

2. Balzacq, T. (2005). The Three Faces of Securitization: Political Agency, Audience and Context. European Journal of International Relations, 11 (2): 171-201.

3. Balzacq, T. (2011). Enquiries into methods: a new framework for securitization analysis, in: Thierry Balzacq (Ed.). Securitization Theory: How Security Problems Emerge and Dissolve. London, New York: Routledge

4. Benecke, O. and DeYoung, S. E. (2019). Anti-Vaccine Decision-Making and Measles Resurgence in the United States. Global Pediatric Health, 6: 1-5.

5. Betsch, C.; Renkewitz, F.; Betsch, T.; Ulshofer, C. (2010). The Influence of Vaccine-critical Websites on Perceiving Vaccination Risks. Journal of Health Psychology, 15 (3): 446-455.

6. Buzan, B. (1983). People, States and Fear: National Security Problem in International Relations. Brighton: Wheatsheaf Books.

7. Buzan, B., Waever, O.; de Wilde, J. (1998). Security: A New Framework for Analysis. Boulder, London: Lynne Rienner publishers. 
8. Calvet, N.; Ashton, J. R. and Garnett, E. (2013). Mumps outbreak in private schools: public health lessons for the post-Wakefield era. Lancet, 38: 1625-1626.

9. Chanel, O.; Luchini, S.; Massoni, S.; Vergnaud. J-C. (2011). Impact of information on intentions to vaccinate in a potential epidemic: Swine-origin Influenza A (H1N1). Social Science \& Medicine, 71: 142-148.

10. Centers for Disease Control and Prevention (2020). Historical Vaccine Safety Concerns. Atlanta: Centers for Disease Control and Prevention. https://www. cdc.gov/vaccinesafety/concerns/concerns-history.htm. (Pregledano 7. oktobra 2020.)

11. Davies, P.; Chapman, S. and Leask, J. (2002). Antivaccination activists on the world wide web. Arch Dis Child, 87: 22-25.

12. Dominus, S. (2011). The Denunciation of Dr. Wakefield. New York Times Magazine, April 2007.

13. Ejdus, F. (2012). Medunarodna bezbednost:Teorije, sektori i nivoi. Beograd: Službeni glasnik, Beogradski centar za bezbednosnu politiku.

14. Ejdus, F. (2009). Opasne veze - Teorija sekuritizacije i Šmitovo nasleđe. Bezbednost Zapadnog Balkana, 4 (13): 9-16.

15. Fitzpatric, M. (2006). The Cutter Incident: How America's First Polio Vaccine Led to a Growing Vaccine Crisis. Journal of the Royal Society of Medicine, 99: 156.

16. Fox, J. G.; Orlova, M.; Schurr, E.; Bliska, B. J. (2016). Tuberculosis in Newborns: The Lessons of the "Lübeck Disaster" (1929-1933). PLOS Pathogens, 12 (1): 1-10. https://journals.plos.org/plospathogens/article?id=10.1371/journal. ppat.1005271. (Pregledano 7. oktobra 2020.)

17. Fuko, M. (2019). Poredak Diskursa. Loznica: Karpos.

18. Gayle, D. i Blackall, M. (2020). Coronavirus sceptics, conspiracy theorists and anti-vaxxers protest in London. The Guardian, 29. Aug 2020. https://www.theguardian.com/world/2020/aug/29/coronavirus-sceptics-conspiracy-theoristsanti-vaxxers-protest-london. (Pregledano 7. oktobra 2020.)

19. Hansen, L. (2000). The Little Mermaid's Silent Security Dilemma and the Absence of Gender in the Copenhagen School. Millennium - Journal of International Studies, 29 (2): 285-306.

20. Hansen, L. (2012). Reconstructing desecuritisation: the normative-political in the Copenhagen School and directions for how to apply it. Review of International Studies, 38: 525-546.

21. Harsin, J. (2015). Regimes of Posttruth, Postpolitics, and Attention Economies. Communication, Culture \& Critique, 8: 327-333.

22. Hendricks, F.V. and Hansen, G. P. (2016). Infostorms: Why do we 'ike?? Explaining individual behavior on the social net. Cham: Spinger.

23. Howell, A. i Richter Montpetit, M. (2020). Is securitization theory racist? Civilizationism, methodological whiteness, and antiblack thought in the Copenhagen School. Security Dialogue, 51 (1): 3-22. 
24. Hotez, P. (2019). America and Europe's new normal: the return of vaccine preventable diseases. Pediatric Research, 85: 912-914.

25. Hussain, A.; Ali, S.; Ahmed, M.; Hussain, S. (2018). The Anti-vaccination Movement: A Regression in Modern Medicine. Cureus, 10 (7): 1-8.

26. Huysmans, J. (1998a). Revisiting Copenhagen: Or, On the Creative Development of a Security Studies Agenda in Europe. European Journal of International Relations, 4 (4): 479-505.

27. Huysmans, J. (1998b). The question of the limit: Desecuritisation and the aesthetics of horror in political realism. Millennium: Journal of International Studies, 27 (3): 569-589.

28. Institut za javno zdravlje Srbije „Dr Milan Jovanović Batut“, Aktuelna epidemiološka situtcija malih boginja (morbila) u Republici Srbiji. Beograd: Institut za javno zdravlje Srbije „Dr Milan Jovanović Batut“. http://www.batut.org. rs/index.php? content $=1629$. (Pregledano 7 . oktobra 2020.)

29. Istinomer (2020). Tabloidi o Koroni \#TimeLine. https://www.istinomer.rs/amnezija/tabloidi-o-koroni-timeline/. (Pregledano 7. oktobra 2020.)

30. Jamison, M. A.; Broniatowski, A. D.; Dredze, M.; Wood-Doughty, Z; Khan, D. i Quinn, C. S. (2019). Vaccine-related advertising in the Facebook Ad Archive. Vaccine, 38 (3): 512-520.

31. Kastels, M. (2018). Mreže revolta i nade: Društveni pokreti u doba interneta. Beograd: Službeni glasnik.

32. Katalinić, M. (2014). Potresna ispovijest liječnice koja je napustila korumpirani medicinski sustav: 'Cijepljenje je najopasnija medicinska praksa u povijesti klasične medicine’. Dnevno HR, 24. veljače 2014. https://www.dnevno.hr/zdravlje/ potresna-ispovijest-lijecnice-koja-je-napustila-korumpirani-medicinski-sustav-cijepljenje-je-najopasnija-medicinska-praksa-u-povijesti-klasicne-medicine-115859/. (Pregledano 7. oktobra 2020.)

33. Keelan, J.; Pavri-Garcia, V.; Tomlinson. G.;Wilson, K. (2007). YouTube as a Source of Information on Immunization: A Content Analysis. JAMA, 298 (21): 2482-2484.

34. Kulenkampff, M.; Schwartzman, J. S. and J. Wilson, J. (1974). Neurological complications of pertussis inoculation. Archives of Disease in Childhood, 49 (1): 46-49.

35. Leonard, S. and Kaunert, C. (2011). Reconceptualizing the audience in securitization theory, in: Thierry Balzacq (Ed.). Securitization Theory: How Security Problems Emerge and Dissolve. London, New York: Routledge.

36. Massey, E. (1722). A sermon against the dangerous and sinful practice of inoculation. https://quod.lib.umich.edu/e/evans/N02782.0001.001? rgn=main;view=fu lltext. (Pregledano 7. oktobra 2020.)

37. McDonald, M. (2008). Securitization and the Construction of Security. European Journal of International Relations, 14 (4): 563-587.

38. Milutinović, I. (2020). Informaciona politika u vreme pandemije virusa „Kovid 19“u Srbiji. Politička Revija, 64 (2): 243-263. 
39. Peters, A. M.; Rider, S.; Hyvönen, M.; Besley, T. (2018). Post-Truth, Fake News: Viral Modernity \& Higher Education. Singapore: Springer.

40. Petrović, D. (2016). Društveno-aktivistički potencijal onlajn platformi za društveno umrežavanje. Sociološki pregled, 1 (3): 397-430.

41. Radovanović, (2017.) Anti-vaccinationists and their arguments in the Balkan countries that share the same language. Srpski arhiv za celokupno lekarstvo, 145 (3-4): 199-24.

42. Riedel, S. (2005). Edward Jenner and the history of smallpox and vaccination. BUMC Proceedings, 18 (1): 21-25.

43. Rosenau, N. J. (2008). People Count! Networked individuals in Global Politics. Boulder, London: Paradigm Publishers.

44. Royal Society for Public Health (2018). Moving the Needle. London: Royal Society for Public Health.

45. Sampson, D. T. (2012). Virality: Contagion Theory in the Age of Networks. Minneapolis, London: University Of Minnesota Press.

46. Searle, J. R. (1969). Speech Acts: An Essay in the Philosophy of Language. Cambridge: at the University Press.

47. Stritzel, H. (2007). Towards a Theory of Securitization: Copenhagen and Beyond. European Journal of International Relations, 13 (3): 357-383.

48. Stecula, D. A.; Kuru, O. and Jamieson, K. H. (2020). How trust in experts and media use affect acceptance of common anti-vaccination claims. The Harvard Kennedy School (HKS) Misinformation Review, January 2020. https://misinforeview.hks.harvard.edu/article/users-of-social-media-more-likely-to-be-misinformed-about-vaccines/. (Pregledano 7. oktobra 2020.)

49. Stojanović Prelević, Lj. (2013). Performativi i refleksivna komunikacijska namera (Doktorska disertacija). Beograd: Univerzitet u Beogradu.

50. Stokić Pejin, Lj. (2016). Tightening measures for compliance with vaccination in Serbia. ESPN Flash Report 2016/46. https://www.europeansources.info/record/ tightening-measures-for-compliance-with-vaccination-in-serbia/. (Pregledano 14. maja 2020.)

51. Sypsa, V.; Livanios, T.; Psichogiou, M.; Malliori, M.; Tsiodras, S.; Nikolakopoulos, I. i Hatzakis, A. (2009). Public Perceptions in relation to intention to receive pandemic influenza vaccination in a random population sample: evidence from a cross-sectional telephone survey. Euro Surveill, 14 (49). http://www.eurosurveillance.org/ViewArticle.aspx?ArticleId=19437. (Pregledano 7. oktobra 2020.)

52. Tebb, W. (1983). Leprosy and vaccination: The recrudescence of leprosy and its causation. London: Swan Sonnenschein \& co. http://www.whale.to/v/tebb/tebb. html. (Pregledano 7. oktobra 2020.)

53. Tobin, M. (2019). Measles cases spike in Indonesia, Malaysia and Philippines as anti-vaxxers take to social media. South China Morning Post, March, 2019. https://www.scmp.com/week-asia/health-environment/article/3003734/measles-vaccine-preventable-diseases-rise-southeast (Pregledano 7. oktobra 2020.) 
54. UNICEF (2013). Tracking Anti Vaccination Sentiment in Eastern European Social Media Networks. New York: UNICEF.

55. Vaidhyanathan, S. (2018). Antisocial Media: How Facebook Disconnects Us and Undermines Democracy. Oxford University Press.

56. Valicon (2020). Istraživanje javnog mnjenja u Srbiji, mart-jul 2020. godine. https://www.cemaforum.rs/docs/1594031767-Saop\%C5\%A1tenje\%20za\%20 medije Valicon_Gra\%C4\%91ani\%20Srbije\%20nemaju\%20poverenje\%20 u\%20zvani\%C4\%8Dne\%20informacije $\% 20 \mathrm{u} \% 20 \mathrm{vezi} \% 20 \mathrm{sa} \% 20$ korona $\% 20$ virusom.pdf. (Pregledano 7. oktobra 2020)

57. Vuori, A. J. (2008). Illocutionary Logic and Strands of Securitization: Applying the Theory of Securitization to the Study of Non-Democratic Political Orders. European Journal of International Relations, 14 (1): 65-99.

58. Zimmerman, K. R.; Wolfe, M. R.; Fox, E. D.; Fox. R. J.; Nowalk, P. M.; A Troy, A. J.; Sharp, K. L. (2005). Vaccine Criticism on the World Wide Web. Journal of Medical Internet Research, 7 (2). https://www.jmir.org/2005/2/e17/. (Pregledano 7. oktobra 2020.)

59. Yaqub, O.; Castle-Clark, S.; Sevdalis, N. i Chataway, J. (2014). Attitudes to vaccination: A critical review. Social Science \& Medicine, 112: 1-11.

60. Waever, O. (1995). Securitization and Desecuritization, in: Ronnie D. Lipschutz (Ed.). On secuirty. New York: Columbia University Press.

61. Wellcome Trust (2018). Wellcome Global Monitor 2018. London: Wellcome Trust. https://wellcome.ac.uk/reports/wellcome-global-monitor/2018/chapter5-attitudes-vaccines. (Pregledano 7. oktobra 2020.)

62. Williams, C. M. (2003). Words, Images, Enemies: Securitization and International Politics. International Studies Quarterly, 47 (4): 511-531.

63. Wolfe, M. R. and Sharp, K. L. (2002). Anti-vaccinationists past and present. BMJ, 325 (7361): 430-432.

64. World Health Organization (2019). Ten threats to global health in 2019. Geneva: World Health Organization. https://www.who.int/. (Pregledano 7. oktobra 2020.) 


\title{
When Audience Becomes an Actor of Securitization: A Shift of the Security Paradigm in the Time of the COVID-19 Pandemic
}

\author{
Vladimir Ajzenhamer \\ University of Belgrade, Faculty of Security Studies, Sebia \\ e-mail: ajzenhamer@fb.bg.ac.rs \\ Vanja Rokvić \\ University of Belgrade, Faculty of Security Studies, Sebia \\ e-mail: vanjarokvic@fb.bg.ac.rs
}

\begin{abstract}
This paper deals with a shift of existing security paradigm and proposes a revision of securitization theory in accordance with current security trends. These trends originate from the new practice of political and security communication, which predominantly relies on the Internet and digital networking. Authors presume that the expansion of the Internet, online media and social networks, has led to the emergence of a new type of securitization, whose core is no longer the state and its elites. Rather, it is conducted by digitally networked citizens. Such securitization, which operates horizontally in the world of digital social networks (and which is largely conditioned by the phenomenon of online virality) authors define as securitization "from below" and call it BTL (below the line) securitization. BTL securitization implies that citizens are no longer assigned the role of (relatively passive) audience, which is the case with the original securitization framework. On the contrary, they appropriate for themselves attributes of the bearer of the securitizing discourse, act as securitizing actor and develop their potential for the implementation of securitization measures.
\end{abstract}

The described shift is currently most noticeable in the field of health security, where the action of so-called anti-vaccine movement gave the first tangible arguments in favor of the initial claim of this paper - the hypothesis of viral "dethronement" of political elites from the position of the dominant securitizing actor. Anti-vaccination movement activities show another important feature of this new securitizing „trend“ - discursive identification of the state (as legitimate securitizer) with the threat that needs to be securitized. In other words, due to the introduction of unpopular measures to combat health threats (e.g., vaccination, quarantine and other types of social restrictions), the government itself is perceived as an existential threat. An illustrative example of this phenomenon is the viral "securitizing" narrative that began spreading among the citizens of Serbia, through social networks, after the outbreak of the COVID-19 global pandemic.

Key words: securitization, BTL, anti-vaxxers, social networks, virality, actor, audience, COVID-19, Republic of Serbia. 